\title{
Antimicrobial Activity of Endophytic and Rhizospheric Fungi Associated with Soft Fern (Christella sp.) and Cinderella Weed (Synedrella nodiflora) Inhabiting a Hot Spring in Los Baños, Laguna, Philippines
}

\author{
Rio Janina B. Arenas, Ren Mark D. Villanueva, Jessica F. Simbahan, PhD and Marie Christine M. Obusan, PhD \\ Microbial Ecology of Terrestrial and Aquatic Systems Laboratory, Institute of Biology, College of Science, University of the Philippines Diliman
}

\begin{abstract}
Background. The growing resistance of microorganisms to antimicrobial agents is a pressing public health issue. Bioprospecting efforts have mainly focused on well-known environments such as soil and animal gut in search for microorganisms with antibiotic production or antimicrobial activity, or terrestrial ecosystems for endemic plants with bioactive compounds. However, microbial communities thriving in stressed environments such as hot springs, are potential sources of metabolites that can be screened for antimicrobial activity. There is a need for research on bioprospecting of fungi as potential sources of antimicrobials.
\end{abstract}

Objectives. The study aimed to test the antimicrobial activity of endophytic and rhizospheric fungi associated with soft fern (Christella spp.) and Cinderella weed (Synederella nodiflora) inhabiting a hot spring in Los Baños, Laguna, Philippines.

Methods. A total of 23 endophytic and rhizospheric fungi isolated from soft fern and Cinderella weed were purified and phenotypically identified. These isolates were subjected to agar well diffusion and agar plug diffusion methods as preliminary assays for antimicrobial activity against Bacillus subtilis var. spizizenii (ATCC ${ }^{\circledR} 6633^{\mathrm{TM}}$ ), Staphylococcus aureus (ATCC ${ }^{\circledR} 25923^{\mathrm{TM}}$ ), four multi-antibiotic resistant Escherichia coli (OT11, OT16, OT18, OT22), and Cladosporium cladosporioides. Based on the results of the preliminary screening, ethyl-acetate extracts of selected fungal isolates were subjected to broth microdilution assay to determine the minimum inhibitory concentrations (MICs) for antibacterial activity, as well as poisoned food technique to determine the percent mycelial inhibition for antifungal activity. The nearest phylogenetic affiliations of fungal isolates with higher antimicrobial activities were determined.

Results. Ten rhizospheric fungal isolates from Cinderella weed and seven rhizospheric and six endophytic fungal isolates from soft fern were phenotypically identified as Aspergillus, Coniothyrium, Fusarium, Penicillium, Talaromyces, and Trichoderma species. Ethyl acetate extracts from endophytic fungal isolates UL1 (Trichoderma sp.) and UL2 (Trichoderma sp.) and rhizospheric fungal isolates UR1 (Trichoderma sp.) and UR3 (Trichoderma sp.) showed activity against the test bacteria at $128-256 \mu \mathrm{g} / \mathrm{mL}$ concentrations. Isolates UL1, UL2, and UR3, which exhibited higher antibacterial activities, were sequenced and confirmed to be most phylogenetically related to Trichoderma virens. Eleven fungal isolates belonging to Aspergillus spp., Coniothyrium spp., Fusarium spp., Penicillium spp., and Talaromyces spp. demonstrated antagonism against C. cladosporioides. The rhizospheric fungal isolate FCRU4 (Talaromyces sp.), from where ethyl acetate extracts were recovered for testing mycelial inhibition, was confirmed to be most phylogenetically related to Talaromyces islandicus.

Paper presented during the $1^{\text {st }}$ International Symposium and Training Workshop on Microbial Utilization in conjunction with $20^{\text {th }}$ MSP Anniversary and $6^{\text {th }}$ Annual AnMicro Conference and iCollect Workshop on April 27, 2019 in SEARCA, University of the Philippines Los Baños, Laguna, Philippines.

Corresponding author: Marie Christine M. Obusan, PhD Microbial Ecology of Terrestrial and Aquatic Systems Laboratory University of the Philippines Diliman

Quezon City 1101, Philippines

Email:mmobusan@up.edu.ph
Conclusion. Endophytic and rhizospheric fungi associated with Cinderella weed (Synedrella nodiflora) and soft fern (Christella sp.) from a hot spring in Los Baños, Laguna, Philippines have antimicrobial activity.

Keywords: endophytic fungi, rhizospheric fungi, CHRISTELLA sp., S. NODIFLORA, antimicrobial activity, hot spring 


\section{INTRODUCTION}

Discovery and development of new antimicrobials are urgently needed to address the growing concern on antimicrobial resistance (AMR) worldwide. ${ }^{1}$ In 2017, the World Health Organization (WHO) provided a priority list of antibiotic-resistant microorganisms. ${ }^{1}$ The list includes 12 families of bacteria, grouped into critical, high, and medium urgency (Table 1).

Table 1. Priority list of antibiotic-resistant microorganisms

\begin{tabular}{cl} 
Urgency & \multicolumn{1}{c}{ Examples } \\
Critical & $\begin{array}{l}\text { Carbapenem-resistant Acinetobacter baumannii, } \\
\text { carbapenem-resistant Pseudomonas aeruginosa, carba- } \\
\text { penem-resistant and ESBL-producing Enterobacteriaceae }\end{array}$ \\
\hline High & Vancomycin-resistant Enterococcus faecium \\
\hline Medium & Penicillin-non-susceptible Streptococcus pneumoniae
\end{tabular}

Source: WHO publishes list of bacteria for which new antibiotics are urgently needed. 2017. ${ }^{1}$

WHO urges researchers to prioritize discovery and development of new antibiotics against drug-resistant Gramnegative bacteria. ${ }^{1}$ As part of the global effort to combat AMR, WHO also launched the Global Antimicrobial Resistance Surveillance System (GLASS), a standardized approach for the collection, interpretation, and dissemination of data to improve the understanding of the impacts of AMR on human health. ${ }^{2}$ In response, the Philippines in 2015 launched the "National Action Plan to Combat Antimicrobial Resistance: One Health Approach" for AMR surveillance, antimicrobial use, and antimicrobial stewardship programs for human and animal health. ${ }^{2}$

Endophytic and rhizospheric fungi are rich sources of bioactive metabolites that have potential applications in medicine. ${ }^{3,4}$ At least $30 \%$ of the bioactive compounds that have been discovered from microorganisms so far, are produced by fungi. ${ }^{5}$ Many bioactive compounds from fungi, such as alkaloids, terpenoids, polyketides, steroids, quinones, phenols, coumarins, and peptides were reported to have antimicrobial activity. ${ }^{6}$ This underscores the importance of fungi in the pipeline for drug discovery. ${ }^{7}$

Endophytic fungi are microorganisms that thrive in plant tissues without causing any disease to the plant. ${ }^{8}$ They inhabit a wide range of hosts such as ferns, grasses, herbaceous and woody plants, and even algae. ${ }^{9}$ Endophytic fungi may assist their host plant in biological processes such as nitrogen-fixation. ${ }^{10}$ Rhizospheric fungi, on the other hand, inhabit the plant root area where they metabolize chemical secretions. ${ }^{11,12}$ One of the known functions of rhizospheric fungi is phosphate solubilization, which increases the availability of soil phosphates for plant utilization. ${ }^{13}$

Several studies confirmed the antimicrobial activity of some endophytic and rhizospheric fungi. Antibacterial activity of the extracts of endophytic fungi Acremonium, Colletotrichum, and Pestalotiopsis associated with Canarium ovatum, a plant endemic to the Philippines, was reported against Staphylococcus aureus, Escherichia coli, Serratia marcescens, Micrococcus luteus, Bacillus subtilis, and Bacillus megaterium. ${ }^{14}$ Extracts of endophytic fungi isolated from medicinal plants (Gliricidia sepium, Canna indica and Gardenia jasminoides) in the province of Bulacan yielded flavonoids, terpenoids, and phenols that have antioxidant property. ${ }^{15}$ The antagonistic activity of rhizospheric fungi Gibellulopsis, Plectosphaerella, Trichoderma, Fusarium, and Chaetomium against the fungal agent of root-rot disease was also confirmed. ${ }^{16}$ The correlation between the antimicrobial activity of some medicinal plants and the proportion of their antagonistic endophytes was reported, suggesting that the phytochemical components of these plants may be directly or indirectly related to their interactions with symbiotic microorganisms. ${ }^{17}$

Rhizospheric and endophytic microorganisms sustain symbiotic relationships by maintaining the health of their host plants..$^{918-20}$ Being sessile, plants are exposed to a wide range of biotic and abiotic stresses that limit their growth and development. ${ }^{18}$ These microorganisms manufacture, or induce the host plant to produce, biologically active compounds that help them adapt to biological stresses. ${ }^{19}$ The likelihood of finding endophytic or rhizospheric microorganisms with unique biochemical properties is greatest in untapped environments (e.g., deserts, hot springs, alpine areas, and the like). ${ }^{21,22}$ The plants of interest in this study, soft fern (Christella sp.) and Cinderella weed (Synedrella nodiflora L.), were collected from a hot spring. ${ }^{23,24}$ Most species of Christella grows in wet, dense or semi-open forests at relatively low elevations, mainly in tropical regions. ${ }^{24-27}$ Christella spp. were reported to demonstrate antibacterial activity against Staphylococcus spp. and Pseudomonas aeruginosa, as well as antifungal effects against causative agents of fungal diseases in groundnuts. ${ }^{26,28}$ There is limited information about the traditional medicinal uses of these ferns, with one species, Christella dentata, reportedly used in Bangladesh as an antihyperglycemic and analgesic. ${ }^{29-31}$ On the other hand, S. nodiflora L. is a native of the tropical parts of the American continent, but now grows in many parts of the world especially in Africa and Southeast Asia. The plant has been traditionally used to treat cardiac problems, wounds, headaches, earaches, and stomachaches, and as liniment for rheumatism. ${ }^{32-34}$ It is also known to contain flavonoids that have antimicrobial, antioxidant, and anti-inflammatory activities. ${ }^{28,29}$ Phenolic compounds isolated from the aerial parts of the plant were reported to have antibacterial and antifungal activities. ${ }^{35}$

This study aimed to screen endophytic and rhizospheric fungi isolated from Cinderella weed ( $S$. nodiflora) and soft fern (Christella sp.) for antibacterial and antifungal activity. Specifically, the study aimed to: (1) identify the isolates based on phenotypic traits; (2) test the antimicrobial activity of these isolates against a selection of bacteria and fungi; and (3) confirm the molecular identification (based on nearest phylogenetic affiliations) of the isolates with higher antimicrobial activity. 


\section{MATERIALS AND METHODS}

\section{Isolation of endophytic and rhizospheric fungi}

The study used previously isolated but unidentifed endophytic $(n=6)$ and rhizospheric $(n=17)$ fungi from host plants Cinderella weed ( $S$. nodiflora) and soft fern (Christella sp.) thriving in Libis ng Nayon, Los Baños, Laguna. The plant samples were collected from two sites: (1) "stressed sites" with water temperature of at least $41^{\circ} \mathrm{C}$ and $\mathrm{pH}$ of 6 (i.e., with the plant's root system submerged in water); and (2) "unstressed sites" with soil temperature of at least $29.5^{\circ} \mathrm{C}$ and $\mathrm{pH}$ of 6 . The differentiation between "stressed sites" and "unstressed sites" was based on temperature. The optimum temperature range for plant growth is $28-30^{\circ} \mathrm{C}$, and $41^{\circ} \mathrm{C}$ can be considered as a stressful condition considering that heat stress denotes temperatures that exceed the optimum values by around $10-15^{\circ} \mathrm{C} .{ }^{36}$ In a temperate climate, heat stress is within the temperature range of $35-40^{\circ} \mathrm{C} .{ }^{37}$

Endophytic fungi were isolated from the leaves while rhizospheric fungi were isolated from the soil surrounding the roots of the plants. For isolation, samples from unstressed sites were incubated at room temperature for 5-7 days while those from stressed sites were incubated at $42^{\circ} \mathrm{C}$ for $5-7$ days.

\section{Phenotypic identification of fungal isolates}

Pure fungal isolates were inoculated onto potato dextrose agar (PDA) plates and were incubated at room temperature for 5-7 days. Whenever growth was observed, the fungi were sub-cultured using the Riddell method. After 7 days, cover slips with hyphal growth were recovered and subjected to microscopic observation. The morphology (i.e., form, size, elevation, margin, surface, opacity, color) of the colonies was noted. In addition, the hyphae of the isolates were observed as to form, type of reproduction, and container and structure of spores. Based on these observations, the isolates were identified up to at least genus level using classification guides for fungi. ${ }^{38-40}$

Isolates with putative phenotypic identifications were screened for antimicrobial activity by performing preliminary screening (agar well diffusion method and agar plug diffusion method), broth microdilution assay, and poisoned food technique. All experiments were carried out in three replications with negative and positive controls.

\section{Preliminary screening for antimicrobial activity}

Agar well diffusion method was performed to determine if the antibacterial activity of the fungal isolates had extracellular origin (i.e., antibacterial compound as filtrate or released in the medium). ${ }^{41}$ Test bacteria were standardized to $0.5 \mathrm{McF}$ arland (approximately $1.5 \times 10^{8}$ cells $/ \mathrm{mL}$ ) using $0.9 \%$ saline solution, and then lawned onto Mueller Hinton agar (MHA) plates. Three wells (6 $\mathrm{mm}$ in diameter) were bored in each of the MHA plates. Meanwhile, fungal isolates grown for 7 days in potato dextrose broth (PDB) were vortexed. One $\mathrm{mL}$ of this was transferred to a microcentrifuge tube and spun at $13500 \mathrm{rpm}$ for 4 minutes. Forty $\mu \mathrm{L}$ of the supernatant, as well as negative control $(\mathrm{PDB})$ and positive control (ampicillin), were inoculated in their respective wells. The MHA plates were then incubated at $37^{\circ} \mathrm{C}$. The zones of inhibition were measured using a caliper. ${ }^{42}$ The test bacteria included B. subtilis var. spizizenii ATCC 6633, $S$. aureus ATCC 25923, and four strains of multi-antibiotic resistant E. coli (isolates OT11, OT16, OT18, OT22).

Agar plug diffusion method was performed to determine if the antibacterial activity of the fungal isolates had intracellular origin (i.e., antibacterial compounds produced by the mycelia). ${ }^{43}$ Test bacteria were standardized to 0.5 McFarland using $0.9 \%$ saline solution, and then lawned onto Mueller Hinton Agar (MHA) plates. Agar plugs (6 mm in diameter) containing cultures of the isolates were obtained from PDA plates incubated at $25-27^{\circ} \mathrm{C}$ for 7 days. The MHA plates with agar plugs and antibiotic discs as controls were then incubated at $37^{\circ} \mathrm{C}$ for 24 hours. ${ }^{39}$ Antibiotics used in control set-ups included erythromycin (i.e., positive control for E. coli), chloramphenicol, and ertapenem. The zone of inhibition formed by agar plugs and discs on MHA were measured using a caliper.

For both agar well and agar plug diffusion methods, antibacterial activity was evaluated as inactive $(<10 \mathrm{~mm})$, partially inactive $(10-13 \mathrm{~mm})$, active $(14-19 \mathrm{~mm})$, and very active $(>19 \mathrm{~mm})$ based on measured zones of inhibition. ${ }^{21}$

The antagonistic activity of the fungal isolates was tested against Cladosporium cladosporioides. Dual culture bioassay was performed wherein each fungal isolate and $C$. cladosporioides were inoculated on PDA plate and observed for growth for at least 7 days until a margin of inhibition was seen. ${ }^{42}$ Observed growths were primarily interpreted as no inhibition (-) or with inhibition $(+)$, and different types of interactions between the two fungi were assessed following Wheeler and Hocking (1993). ${ }^{44}$

\section{Table 2. Types of interaction between two fungi \\ Type Description}

Type A Mutual intermingling growth, where both fungi grew into each other without any macroscopic signs of interaction

Type B Mutual inhibition or space between colonies at a distance $<2 \mathrm{~mm}$

Type C Inhibition of one species on contact, the inhibited species continued to grow at a significantly reduced rate, while the inhibitor species grew at a slightly, reduced rate or unchanged

\begin{tabular}{ll} 
Type D & Mutual inhibition at a distance $>2 \mathrm{~mm}$ \\
\hline Type E & $\begin{array}{l}\text { Inhibition of one species on contact, the inhibitor } \\
\text { species continuing to grow at a reduced rate through the } \\
\text { inhibited colony }\end{array}$ \\
\hline
\end{tabular}

Type F Inhibition of one species on contact or at a distance, the inhibitor species then continuing to grow at an unchanged rate through or over the inhibited colony

Source: Wheeler KA, Hocking AD. Interactions among xerophilic fungi associated with dried salted fish. Journal of Applied Microbiology. 1993. 74(2):164-169. ${ }^{44}$ 


\section{Minimum Inhibitory Concentration (MIC) Assay}

Based on results of the agar plug diffusion and agar well diffusion methods, five fungal isolates (UL4, UL5, UR1, UR2, UR4) were subjected to MIC Assay using the same set of test microorganisms.

Agar plugs (6 mm diameter) obtained from 5-day PDA cultures of fungal isolates were transferred into flasks containing $300 \mathrm{~mL}$ of PDB. ${ }^{45,46}$ The flasks were incubated at $25-27^{\circ} \mathrm{C}$ for 30 days under static and shaking conditions (at a speed of 180 RPM)., ${ }^{3,42}$ After incubation, extracts were obtained from the isolates. Briefly, $250 \mathrm{~mL}$ ethyl acetate (EtOAc) was added to the broth culture and left overnight. ${ }^{46}$ After 24 hours, the filtrate with the EtOAc was removed from the mixture using a separatory funnel for aqueous layer partitioning. ${ }^{46}$ The mycelia were soaked in $150 \mathrm{~mL}$ mixture of water and EtOAc overnight. After 24 hours, the mycelia underwent mechanical grinding, filtration, and partitioning. Crude extracts from both the filtrate and mycelia were recovered through rotary evaporation and then dissolved to a concentration of $10 \mathrm{mg} / \mathrm{mL}$ in dimethyl sulfoxide (DMSO). ${ }^{46}$

Fifty $\mu \mathrm{L}$ of the ethyl acetate extracts prepared from shaking and static conditions was dispensed in assigned wells and were serially diluted two-fold to reach the final concentrations of $256 \mu \mathrm{g} / \mathrm{mL}, 128 \mu \mathrm{g} / \mathrm{mL}, 64 \mu \mathrm{g} / \mathrm{mL}, 32 \mu \mathrm{g} / \mathrm{mL}$, and $16 \mu \mathrm{g} /$ $\mathrm{mL}$ after the addition of $50 \mu \mathrm{L}$ bacterial suspensions (i.e., test bacteria, standardized to $0.5 \mathrm{McF}$ arland). ${ }^{46-48}$ Mueller Hinton Broth (MHB), which was used for serial dilution, served as blank, the standardized bacterial suspension as negative control, and ampicillin and chloramphenicol as positive controls. The cultures were incubated at $37^{\circ} \mathrm{C}$ for 15 hours. After incubation, $10 \mu \mathrm{L}$ of $0.18 \%$ resazurin dye was added to each well. To determine the MIC, plates were checked for color change 3-5 hours after the addition of the resazurin dye.

\section{Poisoned Food Technique}

Based on the demonstrated antagonistic activity of the fungi, the filtrate ethyl acetate extracts of isolate FCRU4 prepared from shaking and static conditions were tested for activity against C. cladosporioides. ${ }^{49,50}$ From a $10 \mathrm{mg}$ / $\mathrm{mL}$ stock solution of the extract, 750, 1500, and $3000 \mathrm{uL}$ were added to $30 \mathrm{~mL}$ of molten PDA media, and then poured into Petri plates to obtain 250, 500 and $1000 \mathrm{ug} /$ $\mathrm{mL}$ extract concentrations, respectively. ${ }^{49,50}$ Each solution was mixed thoroughly and then poured into sterilized plates to solidify. A $5 \mathrm{~mm}$ disc of $C$. cladosporioides, obtained from a 5- to 10-day-old culture grown on PDA, was inoculated at the center of the plate. ${ }^{49}$ Plates were incubated at $28^{\circ} \mathrm{C}$ and the diameter (in $\mathrm{mm}$ ) of fungal colony was measured using a caliper every 24 hours until growth was observed in the control set-ups (sterile water and nystatin). ${ }^{48}$ Percent growth inhibitions of the three extract concentrations were calculated using the equation: ${ }^{51}$

\section{Molecular identification of fungal isolates}

Four isolates (UL1, UL2, UR3, FCRU4), which exhibited higher antimicrobial activities, were selected for confirmation of molecular identification. To extract fungal DNA from these isolates, a lump of mycelia was added to $500 \mu \mathrm{L}$ of lysis buffer (400 mM Tris- $\mathrm{HCl}$ [pH 8.0], $60 \mathrm{mM}$ EDTA [pH 8.0], $150 \mathrm{mM} \mathrm{NaCl}, 1 \%$ sodium dodecyl sulfate). The tube was left for 10 minutes at room temperature before adding $150 \mu \mathrm{L}$ of potassium acetate solution. The solution was briefly vortexed, centrifuged at $>10000 \mathrm{x}$ g for 1 minute, and the supernatant was transferred to a microcentrifuge tube where an equal volume of isopropanol was added. The tube was spun at $>10000 \mathrm{x} g$ for 2 minutes before the supernatant was discarded. The DNA pellet was washed in $300 \mu \mathrm{L}$ of $70 \%$ ethanol. The solution was spun at $10000 \mathrm{rpm}$ for 1 minute before discarding the supernatant. The DNA pellet was air-dried and dissolved in $50 \mu \mathrm{L}$ of $1 \mathrm{x}$ Tris-EDTA. ${ }^{52}$

Primer pair ITS 1 (5'-TCCGTAGGTGAACCTGCGG-3') and ITS 4 (5'-TCCTCCGCTTATTGATATGC-3') was used for the amplification of the ITS-5.8S rDNA. ${ }^{53}$ The conditions for polymerase chain reaction (PCR) were: 5 minutes initial denaturation at $95^{\circ} \mathrm{C}$; $35-$ 37 cycles of (1) denaturation at $95^{\circ} \mathrm{C}$ for 30 seconds, (2) annealing at $55^{\circ} \mathrm{C}$ for 1 minute, (3) extension at $72^{\circ} \mathrm{C}$ for 1 minute; and final extension phase at $72^{\circ} \mathrm{C}$ for 6 minutes. Electrophoresis of PCR products in TAE (Tris-acetateEDTA) buffer was performed on agarose gel (1\%) at $8 \mathrm{~V} / \mathrm{cm}$ with DNA ladder (KAPA Universal ladder). Target DNA bands were $560 \mathrm{bp} .{ }^{54} \mathrm{PCR}$ products were processed for purification, DNA quantification, and sequencing. Phylogenetic analyses were done using MEGA X (Molecular Evolutionary Genetics Analysis ver. 10).

\section{RESULTS}

\section{Phenotypic identification of endophytic and rhizo- spheric fungi}

A total of 23 fungal isolates were phenotypically identified. Ten rhizospheric fungal isolates (SRF1, SFR2, SFR3, SFR4, SFR5, SFR6, SFR7, SFR8, SFR9 \& SFR10) from Cinderella weed ( $S$. nodiflora) were phenotypically identified as Aspergillus with four morphospecies, while seven rhizospheric fungal isolates from soft fern (Christella sp.) were phenotypically identified as Penicillium spp. (FCRU1), Coniothyrium sp. (FCRU2), Aspergillus sp. (FCRU3), Talaromyces sp. (FCRU4) and Trichoderma sp. (UR1, UR2, and UR3). Also, six endophytic fungal isolates from soft fern (Christella sp.) were phenotypically identified as Aspergillus sp. (FCLBU1), Penicillium spp. (FCLBU3), Fusarium sp. (FCLBU2), and Trichoderma spp. (FCLDU1, UL1, UL2) (Table 3). No endophytic fungi were isolated from Cinderella weed ( $S$. nodiflora).

\footnotetext{
$\%$ Growth inhibition $=$ radial diameter of fungus growing on the control plate - radial diameter of fungus on the experimental plate 
Table 3. Endophytic and rhizospheric fungal isolates

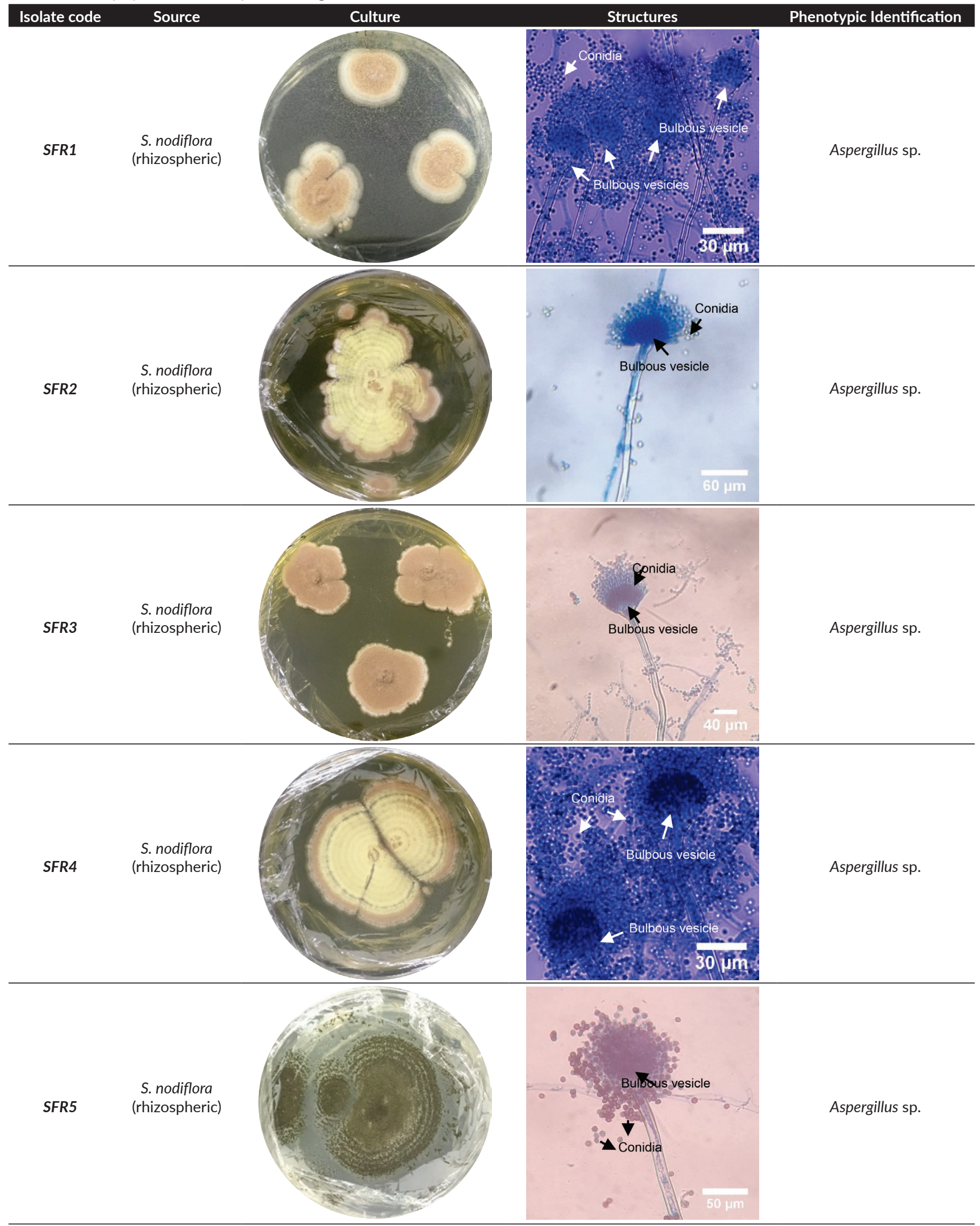


Table 3. Endophytic and rhizospheric fungal isolates (continued)

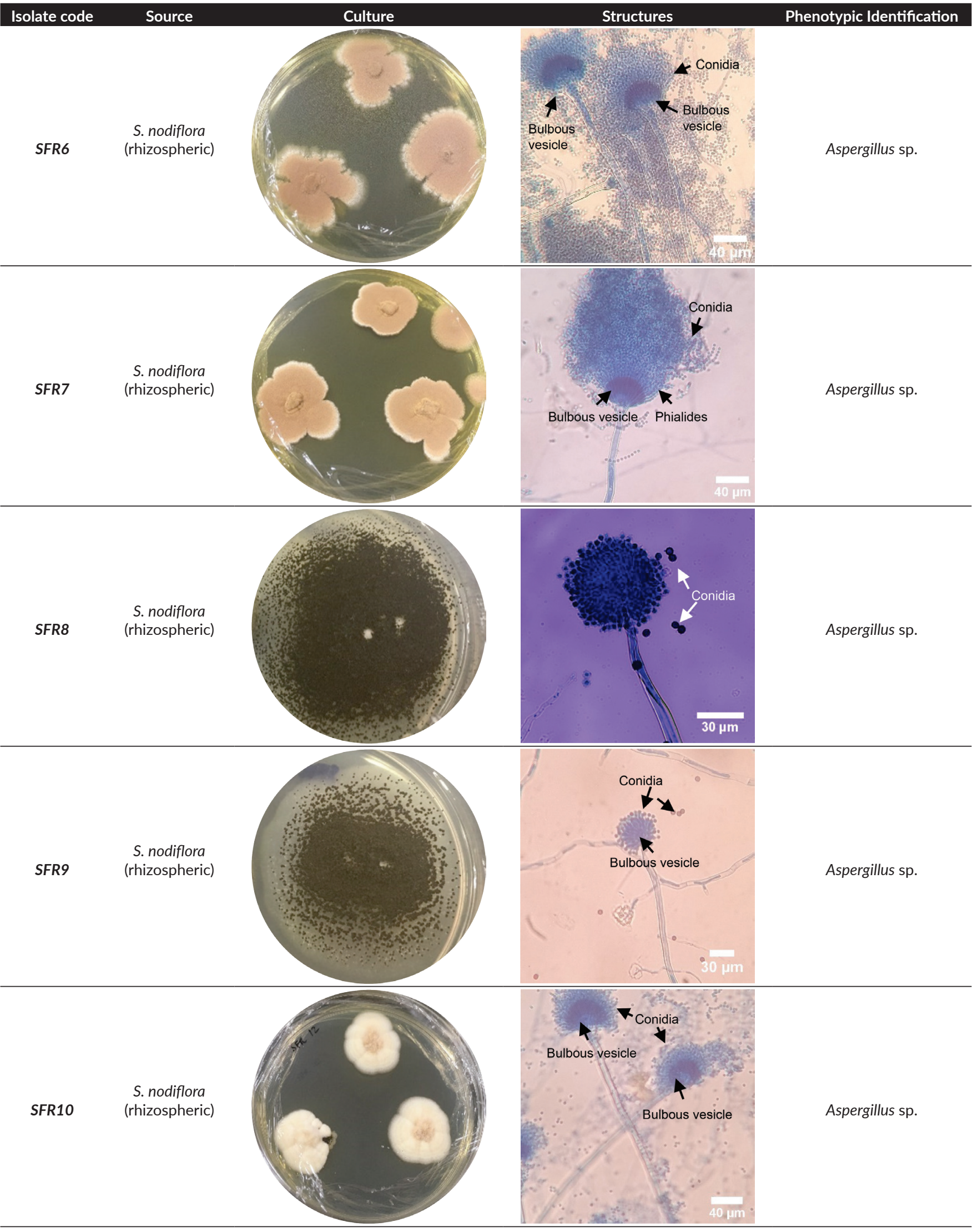


Table 3. Endophytic and rhizospheric fungal isolates (continued)

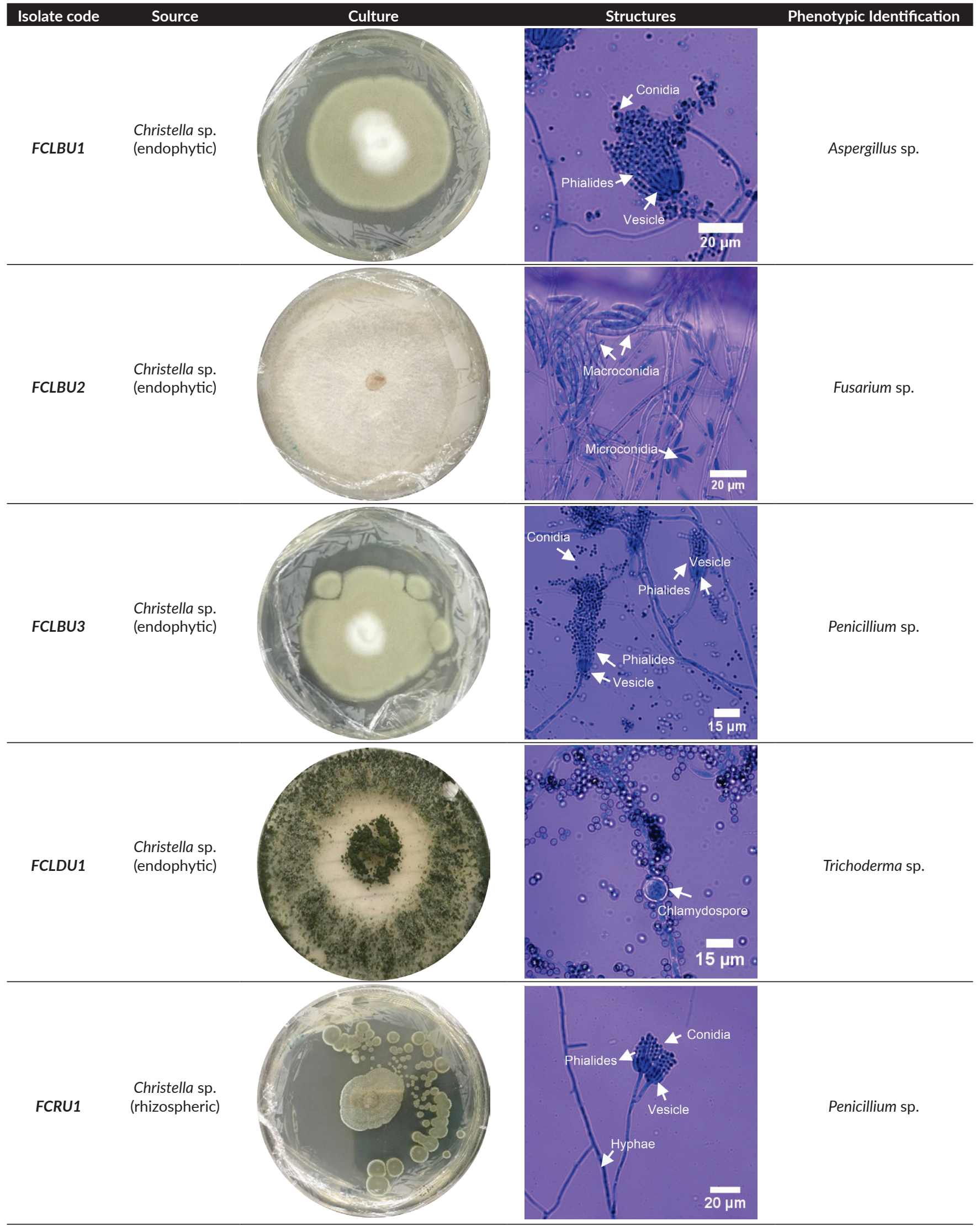


Table 3. Endophytic and rhizospheric fungal isolates (continued)

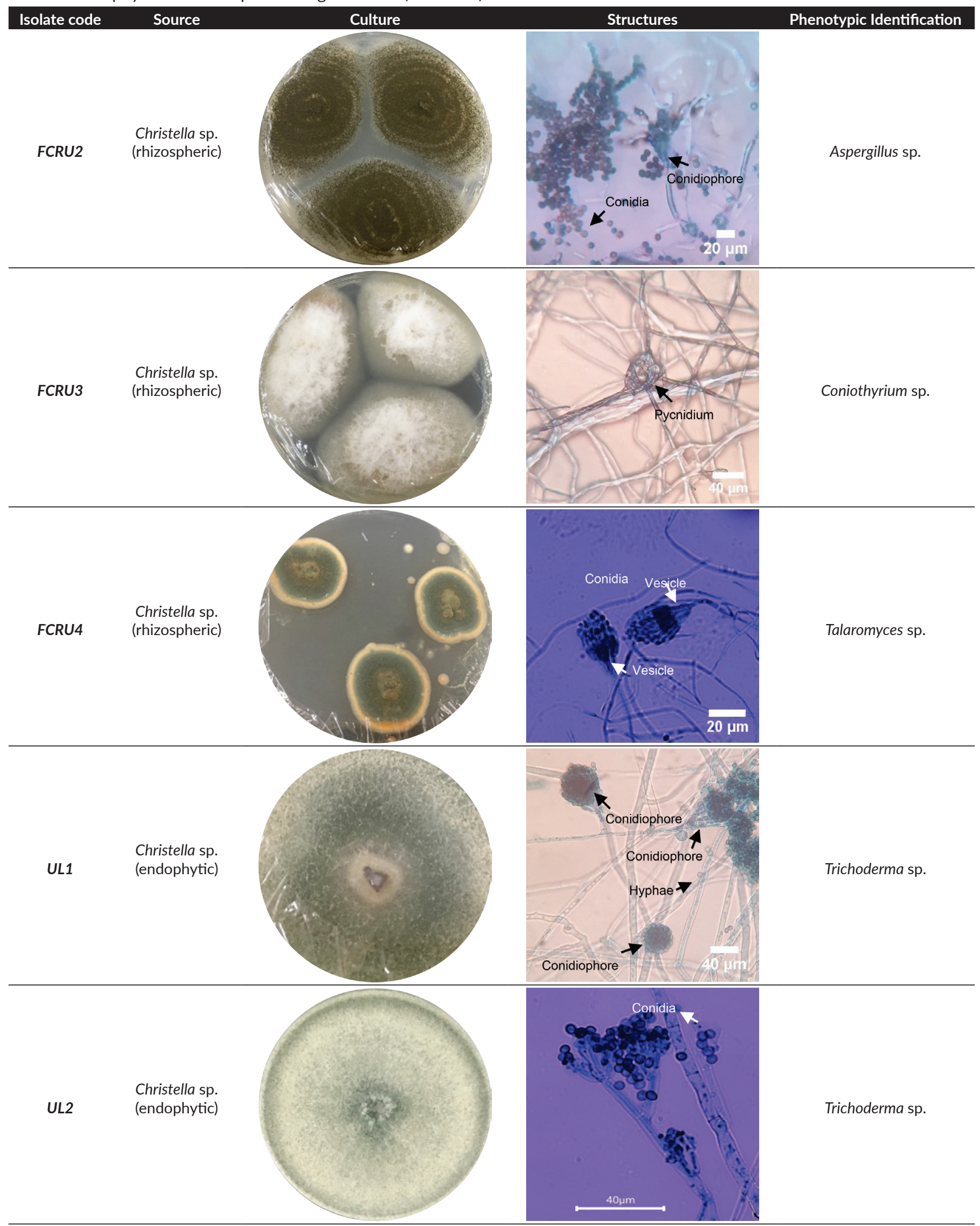


Table 3. Endophytic and rhizospheric fungal isolates (continued)

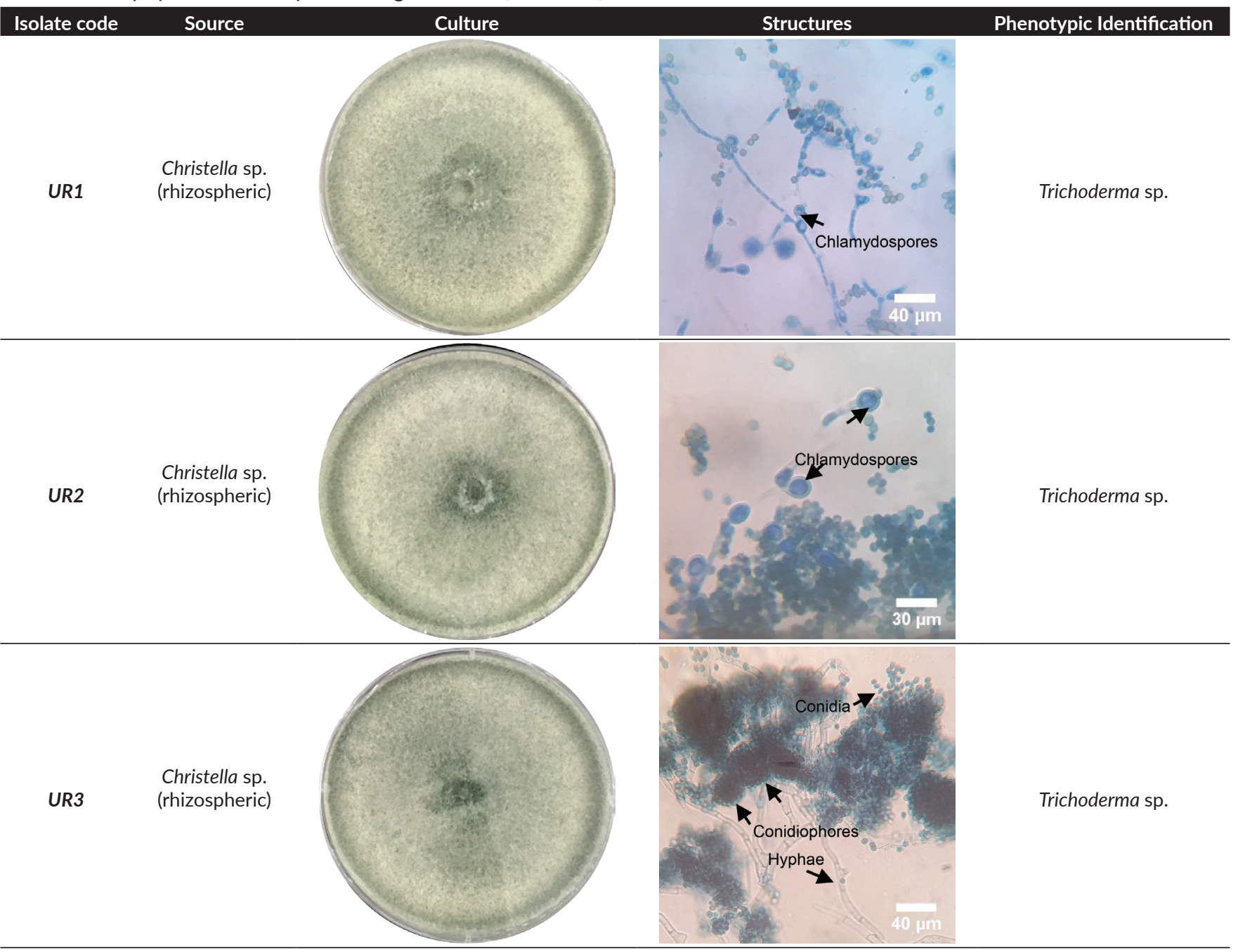

\section{Antibacterial activity of endophytic and rhizo- spheric fungi}

Fifteen (65\%) out of 23 endophytic and rhizospheric fungal isolates showed activity against the test bacteria (Table 4). Of the active isolates, 14 produced intracellular compounds which were found to be active against all test bacteria based on agar plug diffusion method. Five (SFR3, FCRU3, UL1, UR1 and UR3) produced extracellular compounds found to be active only against Gram-positive bacteria (B. subtilis var. spizizenii ATCC 6633 and S. aureus ATCC 25923) based on agar well diffusion method. Overall, five isolates (UL1, UL2, UR1, UR2, and UR3) have relatively broad spectrum, inhibiting both Gram-positive and Gram-negative microorganisms.

\section{Minimum inhibitory concentrations (MICs) of most active isolates}

Based on the results of agar well and agar plug diffusion methods, the five most active isolates (UL1, UL2, UR1, UR2 and UR3) were determined. The filtrate and mycelial crude extracts of these isolates, grown in static and shaking conditions, were subjected to broth microdilution test to determine the MICs against the test bacteria. Isolates UL1, UL2, UR2 and UR3 have MIC values ranging from $128-256 \mu \mathrm{g} / \mathrm{mL}$ against $B$. subtilis var. spizizenii ATCC 6633, S. aureus ATCC 25923, and E. coli isolates (Table 5). A higher proportion of extract concentrations that were effective in inhibiting the growth of bacteria were recovered from isolates grown in shaking conditions. The highest antibacterial activity was shown by the filtrate extract of UR3, with MIC values ranging from 128-256 $\mu \mathrm{g} / \mathrm{mL}$ against all the test bacteria (B. subtilis var. spizizenii ATCC 6633, S. aureus ATCC 25923, and E. coli isolates). The MIC breakpoints for $S$. aureus and E.coli are 0.5-2 $\mu \mathrm{g} / \mathrm{mL}$ and $128 \mathrm{mg} / \mathrm{L}$ respectively. ${ }^{55}$

\section{Antifungal activity of endophytic and rhizo- spheric fungi}

Based on the results of dual culture assay, 11 (47.83\%) out of 23 isolates inhibited the growth of C. cladosporioides 
Table 4. Preliminary screening of antibacterial activity of endophytic and rhizospheric fungi

\begin{tabular}{|c|c|c|c|c|c|c|c|c|c|c|c|c|}
\hline \multirow{3}{*}{$\begin{array}{l}\text { Activity } \\
\text { Against }\end{array}$} & \multicolumn{12}{|c|}{ Zone of Inhibition (or ZOI in $\mathrm{mm}$ ) } \\
\hline & \multicolumn{6}{|c|}{ Agar-well diffusion method } & \multicolumn{6}{|c|}{ Agar-plug diffusion method } \\
\hline & B. subtilis & S. aureus & $\begin{array}{l}\text { E. coli } \\
\text { (OT11) }\end{array}$ & $\begin{array}{l}\text { E. coli } \\
\text { (OT16) }\end{array}$ & $\begin{array}{l}\text { E. coli } \\
\text { (OT18) }\end{array}$ & $\begin{array}{l}\text { E. coli } \\
\text { (OT22) }\end{array}$ & B. subtilis & S. aureus & $\begin{array}{l}\text { E. coli } \\
\text { (OT11) }\end{array}$ & $\begin{array}{l}\text { E. coli } \\
\text { (OT16) }\end{array}$ & $\begin{array}{l}\text { E. coli } \\
\text { (OT18) }\end{array}$ & $\begin{array}{l}\text { E. coli } \\
\text { (OT22) }\end{array}$ \\
\hline Blank (-) & - & - & - & - & - & - & - & - & - & - & - & - \\
\hline Ampicillin (+) & +++ & +++ & - & - & - & - & +++ & +++ & +++ & +++ & +++ & +++ \\
\hline SFR1 & - & - & - & - & - & - & ++ & + & - & - & - & - \\
\hline SFR2 & - & - & - & - & - & - & +++ & + & - & - & - & - \\
\hline SFR3 & + & - & - & - & - & - & ++ & + & - & - & - & - \\
\hline SFR4 & - & - & - & - & - & - & + & + & - & - & - & - \\
\hline SFR5 & - & - & - & - & - & - & - & - & - & - & - & - \\
\hline SFR6 & - & - & - & - & - & - & + & + & - & - & - & - \\
\hline SFR7 & - & - & - & - & - & - & + & - & - & - & - & - \\
\hline SFR8 & - & - & - & - & - & - & - & - & - & - & - & - \\
\hline SFR9 & - & - & - & - & - & - & - & - & - & - & - & - \\
\hline SFR10 & - & - & - & - & - & - & ++ & + & - & - & - & - \\
\hline FCLBU1 & - & - & - & - & - & - & - & - & - & - & - & - \\
\hline FCLBU2 & - & - & - & - & - & - & - & - & - & - & - & - \\
\hline FCLBU3 & - & - & - & - & - & - & - & - & - & - & - & - \\
\hline FCLDU1 & - & - & - & - & - & - & - & - & - & - & - & - \\
\hline FCRU1 & - & - & - & - & - & - & ++ & + & - & - & - & - \\
\hline FCRU2 & - & - & - & - & - & - & - & - & - & - & - & - \\
\hline FCRU3 & - & ++ & - & - & - & - & - & - & - & - & - & - \\
\hline FCRU4 & - & - & - & - & - & - & + & + & - & - & - & - \\
\hline UL1 & + & ++ & - & - & - & - & - & +++ & ++ & ++ & + & ++ \\
\hline UL2 & - & - & - & - & - & - & + & +++ & ++ & ++ & ++ & ++ \\
\hline UR1 & ++ & ++ & - & - & - & - & - & + & +++ & ++ & ++ & ++ \\
\hline UR2 & - & - & - & - & - & - & - & + & ++ & ++ & + & ++ \\
\hline UR3 & + & ++ & - & - & - & - & + & ++ & +++ & +++ & ++ & +++ \\
\hline
\end{tabular}

Activity: - (Inactive, <10 mm ZOI); + (Partially Active, 10-13 mm ZOI); ++ (Active, 14-19 mm ZOI); +++ (Very active, >19 mm ZOI)

Table 5. Minimum inhibitory concentrations (MICs) of fungal isolates tested

\begin{tabular}{|c|c|c|c|c|c|c|}
\hline \multirow{2}{*}{$\begin{array}{c}\text { Isolate } \\
\text { Code }\end{array}$} & \multicolumn{6}{|c|}{ Test Bacteria (MIC, $\mu \mathrm{g} / \mathrm{mL}$ ) } \\
\hline & B. subtilis & S. aureus & $\begin{array}{l}\text { E.coli } \\
\text { (OT18) }\end{array}$ & $\begin{array}{l}\text { E.coli } \\
\text { (OT16) }\end{array}$ & $\begin{array}{c}\text { E.coli } \\
\text { (OT22) }\end{array}$ & $\begin{array}{l}\text { E.coli } \\
\text { (OT11) }\end{array}$ \\
\hline UL1 & $256^{a}$ & $128^{a}$ & $256^{a}$ & & & $256^{a}$ \\
\hline UL2 & & $256^{\mathrm{a}, \mathrm{b}}$ & & & & \\
\hline UR2 & & & $256^{\mathrm{b}}$ & & & \\
\hline UR3 & $\begin{array}{l}128^{b} \\
256^{d}\end{array}$ & $128^{\mathrm{b}}$ & $\begin{array}{l}256^{a, d} \\
128^{b}\end{array}$ & $256^{\mathrm{b}}$ & $256^{b}$ & $256^{\mathrm{b}}$ \\
\hline
\end{tabular}

a Filtrate extract, static condition

${ }^{b}$ Filtrate extract, shaking condition

cMycelial extract, static condition

${ }^{d}$ Mycelial extract, shaking condition

(Table 6). Four different antagonistic interactions were observed: isolate FCRU2 showed a type C interaction, FCLBU2 and FCLBU3 a type $\mathrm{E}$ interaction, SFR5 and FCRU3 a type F interaction, and SFR2, SFR3, SFR4,
SFR6, FCRU1 and FCRU4, a type D interaction (Figure 1). Ethyl acetate extracts (in $250 \mathrm{ug} / \mathrm{mL}, 500 \mathrm{ug} / \mathrm{mL}$ and $1000 \mathrm{ug} / \mathrm{mL}$ concentrations) successfully recovered from FCRU4, did not exhibit activity against the test fungus in the poisoned food technique.

\section{Molecular identification of selected fungal isolates}

The nearest phylogenetic affiliations of fungal isolates with higher antimicrobial activity were determined. Isolates UL1, UL2 and UR3 are most phylogenetically affiliated to Trichoderma virens (GenBank Accession number LT707586) with 98.29\%, 99.22\%, and 99.84\% sequence similarities respectively based on the internal transcribed spacer (ITS) region (Figure 2).

The rhizospheric fungal isolate FCRU4, which yielded ethyl acetate extracts, is most phylogenetically affiliated to Talaromyces islandicus (GenBank Accession number KJ783270) with 99.19\% homology based on the internal transcribed spacer (ITS) region (Figure 3). 
Table 6. Antifungal activity of endophytic and rhizospheric fungi against $C$. cladosporioides

\begin{tabular}{|c|c|c|c|}
\hline Isolate Code & $\begin{array}{l}\text { Phenotypic } \\
\text { Identification }\end{array}$ & $\begin{array}{l}\text { Antifungal } \\
\text { activity }\end{array}$ & $\begin{array}{c}\text { Type of Antagonistic } \\
\text { Interaction }\end{array}$ \\
\hline Blank (-) & N/A & - & N/A \\
\hline Nystatin (+) & N/A & + & $\mathrm{N} / \mathrm{A}$ \\
\hline SFR1 & Aspergillus sp. & - & N/A \\
\hline SFR2 & Aspergillus sp. & + & Type D \\
\hline SFR3 & Aspergillus sp. & + & Type D \\
\hline SFR4 & Aspergillus sp. & + & Type D \\
\hline SFR5 & Aspergillus sp. & + & Type F \\
\hline SFR6 & Aspergillus sp. & + & Type D \\
\hline SFR7 & Aspergillus sp. & - & N/A \\
\hline SFR8 & Aspergillus sp. & - & N/A \\
\hline SFR9 & Aspergillus sp. & - & N/A \\
\hline SFR10 & Aspergillus sp. & - & $\mathrm{N} / \mathrm{A}$ \\
\hline FCLBU1 & Aspergillus sp. & - & N/A \\
\hline FCLBU2 & Fusarium sp. & + & Type E \\
\hline FCLBU3 & Penicillium sp. & + & Type E \\
\hline FCLDU1 & Trichoderma sp. & - & N/A \\
\hline FCRU1 & Penicillium sp. & + & Type D \\
\hline FCRU2 & Aspergillus sp. & + & Type C \\
\hline FCRU3 & Coniothyrium sp. & + & Type F \\
\hline FCRU4 & Talaromyces sp. & + & Type D \\
\hline UL1 & Trichoderma sp. & - & N/A \\
\hline UL2 & Trichoderma sp. & - & N/A \\
\hline UR1 & Trichoderma sp. & - & N/A \\
\hline UR2 & Trichoderma sp. & - & N/A \\
\hline UR3 & Trichoderma sp. & - & N/A \\
\hline
\end{tabular}

Antifungal activity:

- = no inhibition

$+=$ with inhibition

Types of Interaction Observed:

Type $C=$ inhibition of one species on contact, the inhibited species continued to grow at a significantly reduced rate, while the inhibitor species grew at a slightly, reduced rate or unchanged

Type $D=$ mutual inhibition at a distance $>2 \mathrm{~mm}$

Type $E$ = inhibition of one species on contact, the inhibitor species continuing to grow at a reduced rate through the inhibited colony

Type $F=$ inhibition of one species on contact or at a distance, the inhibitor species then continuing to grow at an unchanged rate through or over the inhibited colony

\section{DISCUSSION}

Majority of plant species have not been studied for their associations with fungi, especially plants found in extreme environments. Generally, the diversity of rhizospheric and endophytic fungi varies among plant species, and is affected by several biotic and abiotic factors and stresses..$^{56-57}$ Such information is lacking in the case of soft fern (Christella sp.) and Cinderella weed ( $S$. nodiflora). Ghanta et al. (2012) reported the distribution and diversity of arbuscular mycorrhizal (AM) fungi in the roots of a Christella species,

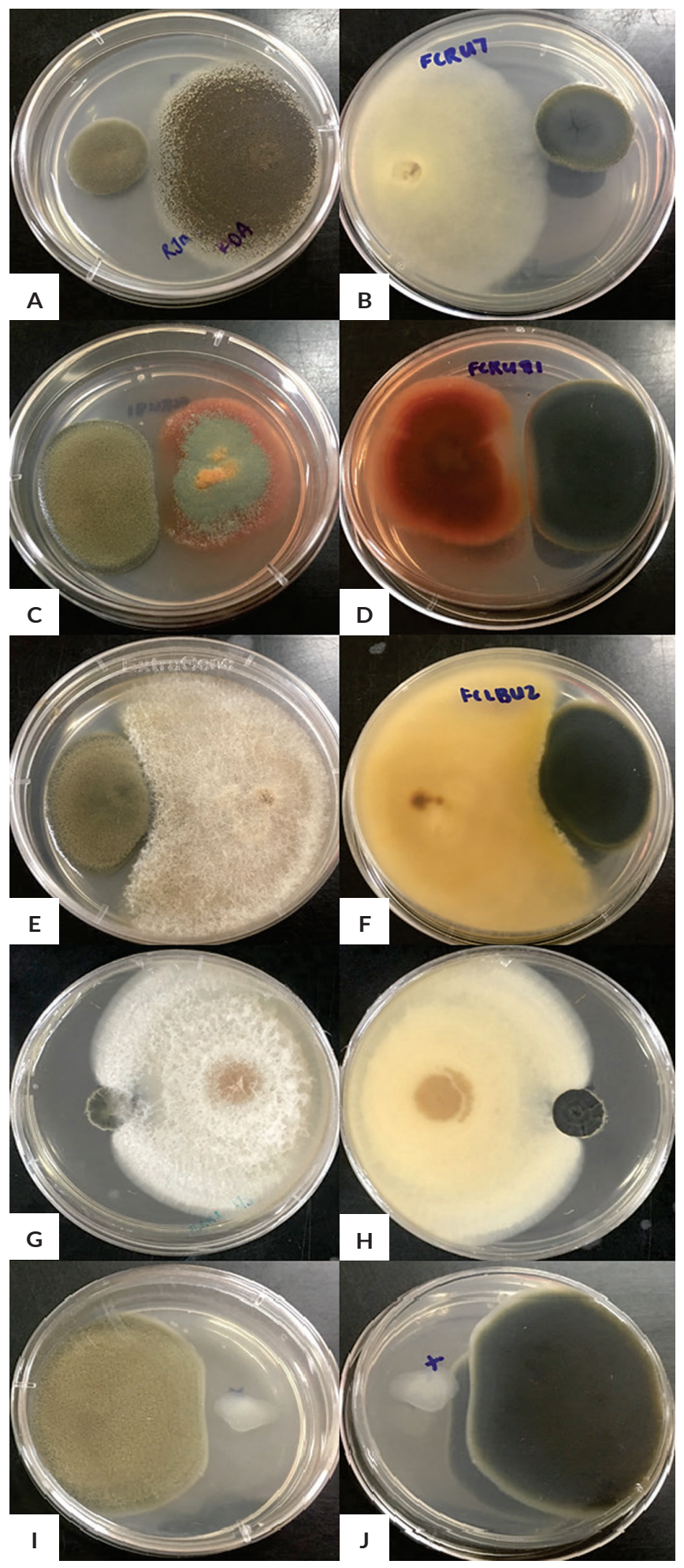

Figure 1. Fungal isolates exhibiting antagonistic interactions against $C$. cladosporioides: (A,B) Aspergillus sp. (FCRU2) showing type $C$ interaction; (C,D) Talaromyces sp. (FCRU4) showing type D interaction; (E,F) Fusarium sp. (FCLBU2) showing type $E$ interaction; (G,H) Coniothyrium sp. (FCRU3) showing type F interaction; and $(\mathbf{I}, \mathrm{J})$ control (nystatin) against $\mathrm{C}$. cladosporioides. 


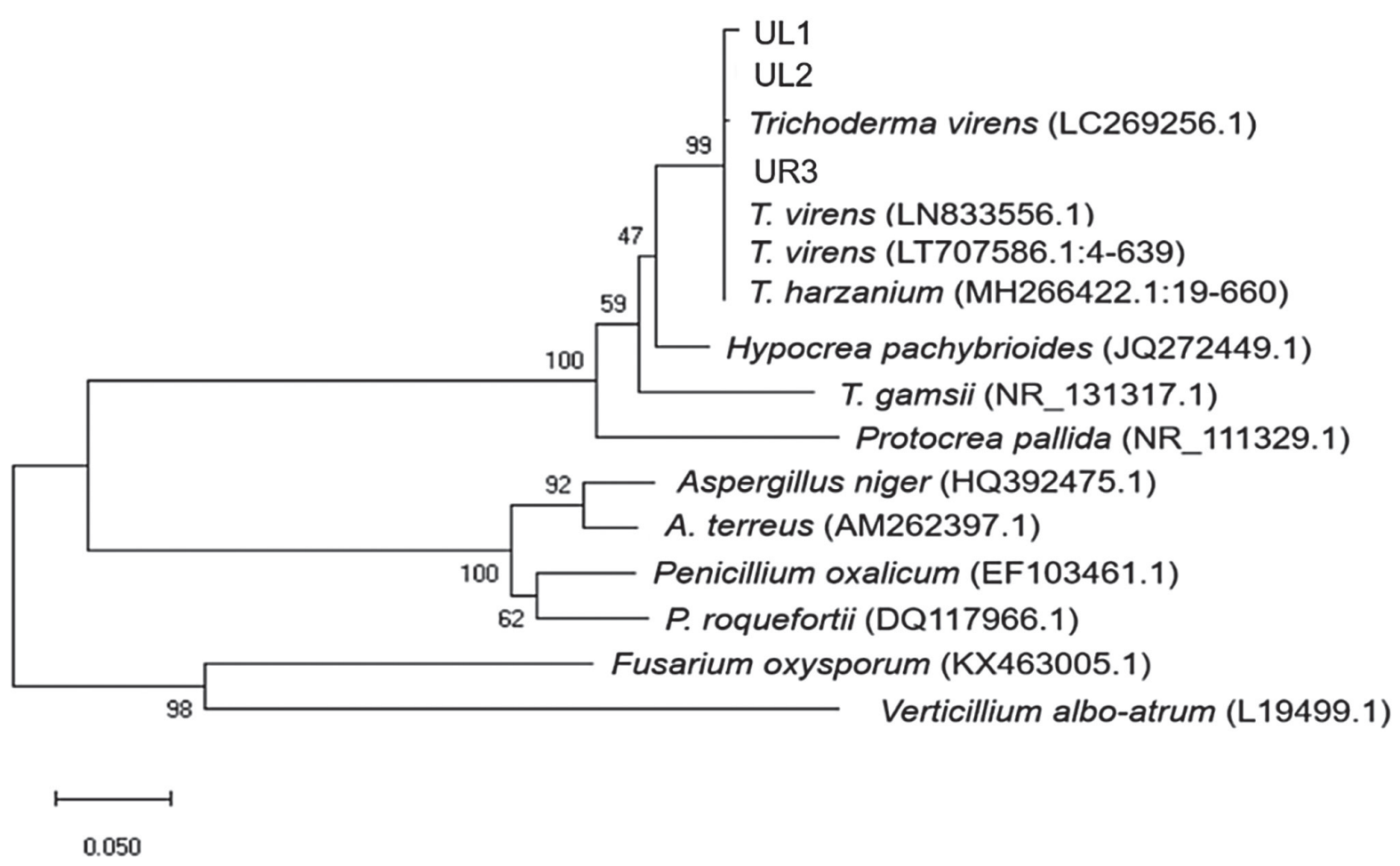

Figure 2. Neighbor-joining tree showing phylogenetic relationships of fungal isolates UL1, UL2, UR3 to other fungi.

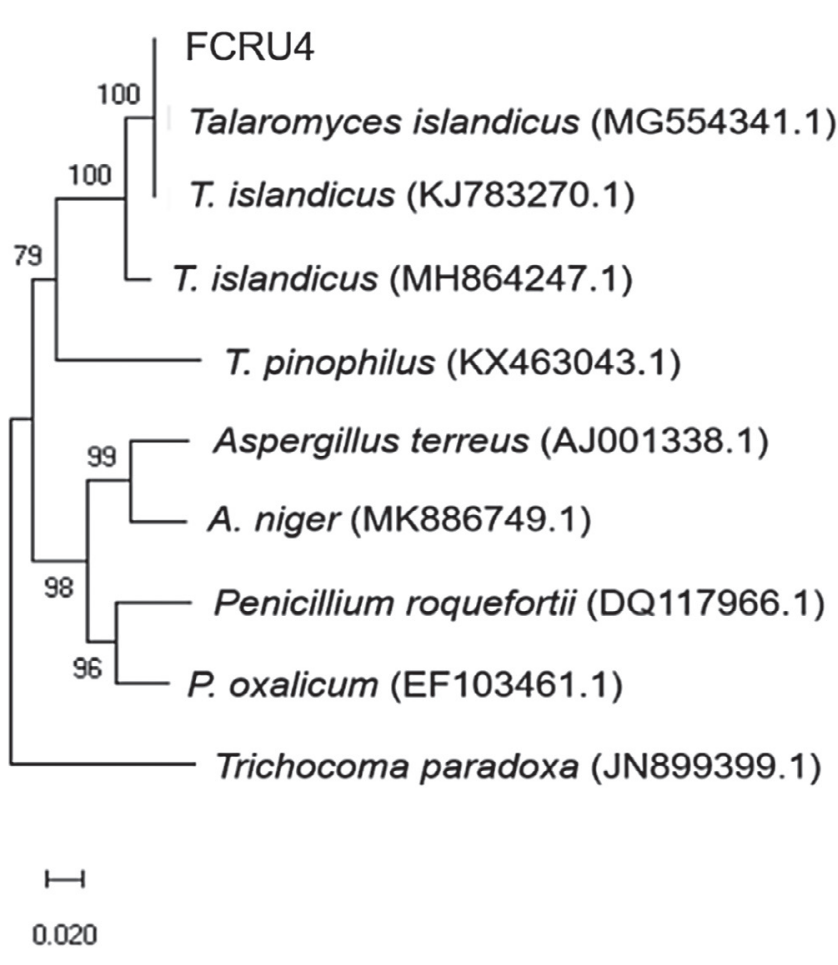

Figure 3. Neighbor-joining tree showing the phylogenetic relationship of FCRU4 to other fungi. the $C$. dentata ${ }^{58}$ while Seerangan et al. (2014) reported the presence of a dark septate endophyte in $S$. nodiflora. ${ }^{23}$

Several studies investigated the mechanisms of symbiotic interactions between microorganisms and their plant hosts. ${ }^{59-61}$ The stresses brought about by thriving in above normal conditions, such as higher temperatures in hot springs, offer selection pressure which could pave the way for novel adaptations such as production of bioactive metabolites (e.g., enzymes, compounds). ${ }^{53-55,59-62}$ In this study, rhizospheric fungal isolates (Aspergillus spp., Coniothyrium sp., Penicillium spp., Talaromyces sp., and Trichoderma sp.) from Cinderella weed ( $S$. nodiflora) and soft fern (Christella sp.) and endophytic fungal isolates (Fusarium sp., Penicillium spp., and Trichoderma spp.) from the latter were taxonomically identified and screened for antimicrobial activity against a selection of bacteria and a pathogenic fungus from a diseased tomato plant.

Less diverse rhizospheric fungi (i.e., only Aspergillus) were isolated from Cinderella weed ( $S$. nodiflora) inhabiting the "stressed" (with the plant's root system submerged in water with a temperature of $41^{\circ} \mathrm{C}$ ) portion compared to the diversity of rhizospheric and endophytic fungi (Penicillium sp., Fusarium sp., Trichoderma sp., Aspergillus sp., Coniothyrium sp. and Talaromyces sp.) isolated from soft fern (Christella spp.) inhabiting the "unstressed" (soil temperature of $29.5^{\circ} \mathrm{C}$ ) portion of the hot spring. It was suggested that rhizospheric fungi thriving in higher temperatures primarily function for heat tolerance, with relatively small energy compensation for antagonism. ${ }^{63-65}$ Ismail et al. (2018), 
reported the potential of Aspergillus to secrete plant growthpromoting hormone and mitigate heat stress by releasing phenols and flavonoids. ${ }^{58,66}$ Rhizospheric fungi such as Aspergillus niger, Fusarium oxusporum, Paecilomyces formosis, Penicillium funiculosum, Penicillium corylophilum, Phoma spp., Rhizopus stolonifera, and Trichoderma spp. were also found to promote host thermotolerance by mediating the regulation of plant endogenous hormones and production of HSP90 (heat shock protein90) inhibitor. ${ }^{67}$ In this study, it was observed that the fungi isolated from Cinderella weed ( $S$. nodiflora) exhibited lower antimicrobial activity compared to the fungi isolated from soft fern (Christella sp.). The rhizospheric fungi associated with Cinderella weed ( $S$. nodiflora) could be functioning for heat tolerance, given that the plant was thriving in a stressed site (i.e., higher temperature).

Overall, the endophytic and rhizospheric fungi belonging to Aspergillus spp., Coniothyrium spp., Fusarium spp. Penicillium spp., Talaromyces spp. and Trichoderma spp. associated with Cinderella weed ( $S$. nodiflora) and soft fern (Christella sp.) were effective against the tested bacteria and fungus. It can be noted that fungal isolates grown in shaking conditions were more effective in inhibiting the growth of test bacteria. The same observation was reported in the case of Trichoderma harzianum, in which cultures grown in shaking condition were more effective in inhibiting the growth of phytopathogenic bacteria Xanthomonas campestris and Clavibacter michiganensis compared to cultures grown in static condition. ${ }^{47}$

Aspergillus spp. have documented antagonistic activity against pathogens. ${ }^{68} A$. niger has the ability to suppress sheath blight caused by Rbizoctonia solani. ${ }^{69} A$. niger, $A$. flavus, and A. terreus suppressed the colonization of Fusarium udum, which causes wilt disease of pigeon-pea. ${ }^{70}$ Nonaflatoxigenic strains of Aspergillus were used to control aflatoxigenic strains. ${ }^{71,72}$

A species of Coniothyrium, is a known biocontrol agent of pathogenic fungi. The mycoparasite Coniothyrium minitans is used as biocontrol for Sclerotinia spp. (sclerotium, minor, and trifoliorum). ${ }^{73-81}$ A commercial product of the mycoparasite (Constanz) is commercially registered and available in Europe and USA. ${ }^{74,78,82}$ The culture filtrates of C. minitans can inhibit mycelial growth of S. sclerotiorum. ${ }^{83}$ Also, C. minitans produces antifungal substances, such as macrosphelide A. ${ }^{82}$ antifungal substances produced by C. minitans strain Chy-1, inhibits growth of mycelia, extension of germ tubes of ascospores, and germination of myceliogenic sclerotia of $S$. sclerotium, and reduces the incidence of rapeseed (Brassica napus) leaf blight caused by S. sclerotium. ${ }^{84}$ Aside from mycoparasitism, the production of antifungal substances can be exploited as another mechanism for antifungal activity of Coniothyrium spp. ${ }^{81}$ In the present study, it is possible that isolate FCRU3 (Coniothyrium sp.) either produces antifungal substances or acts as a mycoparasite to $C$. cladosporioides, as indicated by the antagonistic reaction.
Fusarium spp. are also used as biocontrol agents. Some pathogenic strains of $F$. oxysporum, which cause serious damage on many agricultural crops, are controlled with the use of nonpathogenic $F$. oxysporum that exhibit either direct or indirect antagonism mediated through the host plant. ${ }^{85,86}$ The use of nonpathogenic strains of $F$. oxysporum to control Fusarium wilt has also been reported in numerous crops and field trials (e.g., banana, strawberry, and tomato). ${ }^{87-89}$

Since the discovery of penicillin, thousands of Penicillium isolates have been screened and new metabolites discovered through bioprospecting programs..$^{90}$ Penicillium species are known to produce numerous bioactive compounds, including mycotoxins, herbicides, antioxidants, insecticides, antibiotics, antifungal substances and anticancer compounds. ${ }^{91-94}$ Some of the extracted and characterized compounds from terrestrial Penicillium strains are mycophenolic acid, griseofulvin, and 3-O-methylfunicone. ${ }^{95-98}$ The antifungal activity of Penicillium spp. against Colletotrichum acutatum, F. oxysporum, Fusarium solani, Macrophomina phaseolina, Aspergillus japonicus var. aculeatus and C. cladosporioides has been reported. ${ }^{92,94}$

Talaromyces spp. are Penicillium that produces sexual structures, such as cleistothecia, asci, and ascospores), and which also produce a variety of active compounds such as tetraene lactones, diphenyl ether derivatives, epiaustdiol, furanosteroid and anthraquinones. ${ }^{99-104}$ Eighty-eight compounds have been recovered from Talaromyces spp. and evaluated for cytotoxic, antiproliferative, immunosuppressive, antimicrobial, and enzyme inhibitory activities. ${ }^{105}$ Emodin, skyrin, norlichexanthone, secalonic acid A, and stemphyperylenol, extracted from Talaromyces sp. ZH154 endophytic to the mangrove tree (Kandelia candel (L.) Druce), were found to be active against E. coli, S. aureus, Pseudomonas aeruginosa, A. niger and Candida albicans. ${ }^{106}$ Additionally, T. flavus has demonstrated the ability to reduce the viability and apothecial production of the pathogen S. sclerotiorum with its production of hydrogen peroxide as the main bioactivity mechanism. ${ }^{107,108}$

Trichoderma are well known producers of secondary metabolites against phytopathogens. ${ }^{99,100,109}$ Some Trichoderma spp., usually isolated as endophytes especially in tropical vegetations, have minimal nutritional needs and produce a plethora of secondary metabolites including peptaibols, gliotoxin, gliovirin, polyketides, pyrones, and terpenes that have activity against pathogenic bacteria, yeasts and filamentous fungi. ${ }^{107-112}$ The antifungal compound, trichodermin, was isolated from Trichoderma koningiopsis, which exhibited strong fungicidal effects against Aspergillus fumigatus, Pyricularia oryzae and Botrytis cinerea. ${ }^{109}$ Antimicrobial activity of Trichoderma was reported by Leylaie et al. (2018), which confirmed the antibacterial activity of seven endophytic Trichoderma species isolated from (Vinca sp.) against $S$. aureus, E. coli, Ralstonia solanacearum and Clavibacter michiganensis, and Santos et al. (2018), which documented the eradication of staphylococcal biofilms by 
the ethanolic extracts of Trichoderma asperelloides. ${ }^{109,100}$ In this study, it can be noted that only Trichoderma spp. (isolates UL1, UL2, UR1, UR2, and UR3) exhibited activity against the E. coli isolates.

This study confirmed the antibacterial activity of the endophytic and rhizospheric fungi in clinically significant bacteria. The E.coli isolates that were used in the assays were resistant to ampicillin, cephalothin, ciprofloxacin, ertapenem, erythromycin, moxifloxacin, ofloxacin, tetracycline, imipenem, oxytetracycline and sulfamethoxazole (Obusan et al. 2017, unpublished data). In general, there is increasing trend of E. coli resistance against ampicillin, amoxicillin and trimethoprimsulfamethoxazole. ${ }^{113-115}$ The other test bacterium used, $S$. aureus, has resistant strains (e.g., methicillin-resistant $S$. aureus or MRSA) and is a public health concern - causing staphylococcal infections in health care and community settings. ${ }^{116,117}$ There is a growing evidence supporting the role of Bacillus spp. in the dissemination of antibiotic resistance genes in the food industry. Bacillus spp., in commercially available probiotic feeds, were found to be resistant to chloramphenicol, tetracycline, erythromycin, lincomycin, penicillin, and streptomycin. ${ }^{118-123}$ This study also confirmed the antagonistic activity of the fungal isolates against $C$. cladosporioides, which was isolated from a diseased tomato plant (Rey, 2019; personal communication). This fungal pathogen is known to affect several plants (e.g., mandarin, grape, wheat and strawberry), causing blight disease. ${ }^{124-125}$

\section{CONCLUSION}

Endophytic and rhizospheric fungi associated with Cinderella weed (S. nodiflora) and soft fern (Christella sp.) from a hot spring in Los Baños, Laguna, Philippines are potential sources of antimicrobials. Four fungal isolates identified as Trichoderma spp. inhibited B. subtilis var. spizizenii ATCC 6633, S. aureus ATCC 25923, and multi-antibiotic resistant $E$. coli isolates, with MIC values ranging from $128-256 \mu \mathrm{g} / \mathrm{mL}$. On the other hand, eleven fungal isolates identified as Aspergillus spp., Coniothyrium spp., Fusarium spp., Penicillium spp., and Talaromyces spp. showed antagonism against the plant phytopathogen $C$. cladosporioides. The nearest phylogenetic affiliations of fungal isolates with promising antimicrobial activity were known: UL1, UL2 and UR3 are most phylogenetically affiliated to Trichoderma virens while FCRU4 to Talaromyces islandicus. The antimicrobial activity of these fungi must be optimized and the specific mechanisms need to be elucidated for various applications.

\section{Statement of Authorship}

All authors have approved the final version of the manuscript.

\section{Author Disclosure}

All authors declared no conflicts of interest.

\section{Funding Source}

Microbial Ecology of Terrestrial and Aquatic Systems Laboratory

\section{Availability of data and materials}

All data generated are included in the article. Other relevant data may be requested through the corresponding author.

\section{REFERENCES}

1. WHO publishes list of bacteria for which new antibiotics are urgently needed [ Internet]. 2017 [cited 2018 Sept], Available from: https:// www.who.int/news-room/detail/27-02-2017-who-publishes-listof-bacteria-for-which-new-antibiotics-are-urgently-needed.

2. World Health Organization (WHO). Global antimicrobial resistance surveillance system (GLASS) report: Early implementation 20162017. Geneva: World Health Organization. 2017.

3. Gouda S, Das G, Sen SK, Shin H, Patra JK. Endophytes: A treasure house of bioactive compounds of medicinal importance. Frontiers in Microbiology. 2016; 7(148):1-8.

4. Strobel G, Daisy B, Castillo U, Harper J. Natural products from endophytic microorganisms. Journal of Natural Products. 2004; 67(2):257-68.

5. Mahajan GB. Antibacterial agents from actinomycetes - A review. Frontiers in Bioscience. 2012; 1(4):240-53.

6. Mullis MM, Rambo IM, Baker BJ, Reese BK. Diversity, ecology and prevalence of antimicrobials in nature. Frontiers in Microbiology. 2019; 10(2518):1-23.

7. Toghueo RMK. Bioprospecting endophytic fungi from Fusarium genus as sources of bioactive metabolites. Mycology. 2019; 1:1-21.

8. Tacconelli E, Carrara E, Savoldi A, Harbarth S, Mendelson M, Monnet DL. et al., Discovery, research, and development of new antibiotics: The WHO priority list of antibiotic-resistant bacteria and tuberculosis. Lancet Infect Dis. 2018; 18(3):318-27.

9. Tanaka A, Tapper BA, Popay A, Parker EJ, Scott B. A symbiosis expressed non-ribosomal peptide synthetase from a mutualistic fungal endophyte of perennial ryegrass confers protection to the symbiotum from insect herbivory. Mol Microbiol. 2005; 57(4):1036-50.

10. Ngwene B, Boukail S, Söllner L, Franken P, Andrade-Linares DR. Phosphate utilization by the fungal root endophyte Piriformospora indica. Plant and Soil. 2015; 405(1-2):231-41.

11. McNear Jr, DH. The rhizosphere - Roots, soil and everything in between. Nature Education Knowledge. 2013; 4(3):1.

12. Rebecca L, Dhanalakshmi V, Sharmila S, Susithra G, Kumar S, Bala S. Isolation, identification and characterization of fungi from rhizosphere soil of Barleria cristata. Int J Hort Sci Tech. 2012; 2(1):1-6.

13. Elias F, Woyessa D, Muleta D. Phosphate solubilization potential of rhizosphere fungi isolated from plants in Jimma zone, Southwest Ethiopia. Int J Microbiol. 2016;1-11.

14. Torres JO, Dela Cruz TE. Antibacterial activities of fungal endophytes associated with the Philippine endemic tree, Canarium ovatum. Mycosphere. 2015; 6(3):266-73.

15. Eskandarighadikolaii S, dela Cruz TE, Bungihan M. Antioxidant properties of fungal endophytes associated with the three medicinal plants Gliricidia sepium, Canna indica and Gardenia jasminoides. J Sci Res Rep. 2015; 6(3):217-26.

16. Miao C, Mi Q, Qiao X, Zheng Y, Chen Y, Xu L et al. Rhizospheric fungi of Panax notoginseng: Diversity and antagonism to host phytopathogens. J Ginseng Res. 2016; 40(2):127-34

17. Egamberdieva D, Wirth S, Behrendt U, Ahmad P, Berg G. Antimicrobial activity of medicinal plants correlates with the proportion of antagonistic endophytes. Front Microbiol. 2017; 8(199):1-11.

18. Lata R, Chowdhury S, Gond SK, White JF, Jr. Induction of abiotic stress tolerance in plants by endophytic microbes. Lett Appl Microbiol, 2018; 66(4):268-76. 
19. Khare E, Mishra J, Arora NK. Multifaceted interaction between endophytes and plant: Developments and prospects. Front Microbiol. 2018; 9(2732):1-12.

20. Vega FE, Posada F, Aime MC, Pava-Ripoll M, Infante F, Rehner SA. Entomopathogenic fungal endophytes. Biol Control. 2008; 46(1): 72-82.

21. Strobel G. The emergence of endophytic microbes and their biological promise. J Fungi. 2018; 4(2):1-19.

22. Gutierrez RMP, Gonzalez AMN, Ramirez AM. Compounds derived from endophytes: A review of phytochemistry and pharmacology. Curr Med Chem. 2012; 19(18):2992-3030.

23. Seerangan K, Thangavelu M. Arbuscular mycorrhizal and dark septate endophyte fungal associations in South Indian aquatic and wetland macrophyte. J Bot. 2014; (173125):1-14.

24. Ghanta R, Dutta S, Mukhopadhyay R. Occurrence of dark septate endophytes in the sporophytes of Christella dentata. Am Fern J. 2012; 102(3):216-23.

25. Bycroft YM, Illeogbulam NG, Gbekeleoluwa AR. Phytochemical and antimicrobial studies on the aerial parts of Synedrella nodiflora Linn. Ann Biol Res. 2014; 5(1):59-63.

26. Paul KR, Irudayaraj V, Johnson M, Patric DR. Phytochemical and antibacterial activity of epidermal glands extract of Christella parasitica (L.) H. Lev. Asian Pac J Trop Biomed. 2011; 1(1):8-11.

27. Xu CL, Su T, Huang J, Huang YJ, Li SF, Zhao YS, Zhou ZK. Occurrence of Christella (Thelypteridaceae) in Southwest China and its indications of the paleoenvironemnt of the Qinghai-Tibetan Plateau and adjacent areas. J Syst Evol. 2018; 169-79.

28. Sahayaraj K, Borgio JF, Raju G. Antifungal activity of three fern extracts on causative agents of groundnut early leaf spot and rust diseases. Journal of Plant Protection Research, 2009. 49(2), 141-144.

29. Tanzin R, Rabman S, Hossain S, Agarwala B, Khatun Z, Jahan S, Rahman M, Mou SM, Rahmatullah M. Medicinal potential of pteridophytes and antinociceptive activity evaluation of methanolic extract of whole plants of Christella dentata. Advances in Natural and Applied Sciences, 2013.7(1), 67-73.

30. Baskaran XR, Geo Vigila AV, Zhang SZ, Feng SX, Liao WB. A review of the use of pteridophytes for treating human ailments. Journal of Zhejiang University Science B, 2018. 19(2), 85-19.

31. Thomas T. Antibacterial evaluation of fronds of Christella dentata (Forssk.) Brownsey \& Jermy. Journal of Natural Products and Resources, 2015.1(1), 17-18.

32. Idu M, Onyibe HI. Medicinal plants of Edo State, Nigeria. Research Journal of Medicinal Plants, 2007. 2, 32-41.

33. Burkhill HM, Abbiw DK. The useful plants of West Tropical Africa. (2nd. Ed.) Kew: Royal Botanical Gardens. 1985

34. Amoateng P, Woode E, Kombian SB. Anticonvulsant and related neuropharmacological effects of the whole plant extract of Synedrella nodiflora (L.) Gaertn (Asteraceae). Journal of Pharmacy \& Bioallied Sciences, 2012. 140-148.

35. Bidam YM, Illeogbulam NG, Gbekeleoluwa AR. Phytochemical and antimicrobial studies on the aerial parts of Synedrella nodiflora Linn. Annals of Biological Research, 2014. 5(1), 59-63.

36. Wahid A, Gelani S, Ashraf M, Foolad MR. Heat tolerance in plants: An overview. Environmental and Experimental Botany, 2007. 61(3), 199-223.

37. Larkindale J, Mishkind M, Vierlign E. Plant responses to high temperature. In: Plant Abiotic Stress. Jenks M, Hasegawa PM, editors. Oxford Ames Carlton: Blackwell Publishing. 2005. p. 100-134.

38. Williams-Woodward, J. Simplified fungi identification key. Georgia: University of Georgia. 2001

39. Guarro J, Gene J, Stchigel AM. Developments in fungal taxonomy. Clinical Microbiology Reviews, 1999. 12(3), 454-500.

40. Benson HJ. Microbiological applications: Laboratory manual in general microbiology. Boston: McGraw-Hill. 2002.

41. Sabdaningsih A, Cristianawati O, Sibero MT, Nuryadi H, Radjasa OK, Sabdono A, Trianto A. Screening antibacterial agent from crude extract of marine-derived fungi associated with soft corals against MDR-Staphylococcus aureus. IOP Conference Series: Earth and Environmental science. 2017.1-8.
42. Balouiri M, Sadiki M, Ibnsouda SK. Methods for in vitro evaluating antimicrobial activity: A review. Journal of Pharmaceutical Analysis, 2016. 6(2), 71-79.

43. Manikkam R, Venugopal G, Subramaniam B, Ramasamy B, Kumar $\mathrm{V}$. Bioactive potential of actinomycetes from less explored ecosystems against Mycobacterium tuberculosis and other nonmycobacterial pathogens. International Scholarly Research Notices, 2014. 2014(812974):1-9.

44. Wheeler KA, Hocking AD. Interactions among xerophilic fungi associated with dried salted fish. Journal of Applied Microbiology. 1993. 74(2):164-169.

45. Avinash KS, Ashwini HS, Babu HN, Krishnamurthy YL. Antimicrobial potential of crude extract of Curvularia lunata, an endophytic fungi isolated from Cymbopogon caesius. Journal of Mycology, 2015, 2015(185821):1-4.

46. Supaphon P, Phongpaichit S, Rukachaisirikul V, Sakayaroj J. Antimicrobial potential of endophytic fungi derived from three seagrass species: Cymodocea serrulata, Halophila ovalis and Thalassia hemprichii. PLoS ONE, 2013. 8(8), 1-9.

47. Anwar J, Iqbal Z. Effect of growth conditions on antibacterial activity of Trichoderma harzianum against slected pathogenic bacteria. Sarhad Journal of Agriculture. 2017. 501-511.

48. Nayim P, Mbaveng AMT, Wambe BEN, Fankam AG, Dzotam JK, Kuete V. Antibacterial and antibiotic-potentiating activities of thirteen Cameroonian edible plants against Gram-negative resistant phenotypes. Scientific World Journal. 2018. 2018 (4020294): $1-14$.

49. Ibrahim M, Kaushik N, Sowemimo A, Chhipa H, Koekemoer T, van de Venter M, Odukoya OA. Antifungal and antiproliferative activities of endophytic fungi isolated from the leaves of Markhamia tomentosa. Pharmaceutical Biology. 2017. 55(1), 590-595.

50. Chowdhary K, Kaushik N. Fungal endophyte diversity and bioactivity in the Indian medicinal plant Ocimum sanctum Linn. PLoS One. 2015. 0141444.

51. Ingle KP, Deshmukh AG, Padole DA, Dudhare MS, Moharil MP, Khelurkar C, Gangtire DR. Bioassay guided fractionation of antifungal activity of Jatropha curcas. Journal of Pharmacognosy and Phytochemistry, 2017. 6(6), 2147-2154.

52. Liu D, Coloe S, Baird R, Pederson J. Rapid mini-preparation of fungal DNA for PCR. Journal of Clinical Microbiology. 2000. 38(1), 471.

53. Solis MJL, Dela Cruz TE, Schnittler M, Unterseher M. The diverse community of leaf-inhabiting fungal endophytes from Philippine natural forests reflects phylogenetic patterns of their host plant species Ficus benjamina, F. elastica and F. religiosa. Mycoscience. 2016. 57(2):96-106.

54. Kamle, M. A Species-specific PCR based assay for rapid detection of mango anthracnose pathogen Colletotrichum gloeosporioides Penz. and Sacc. Journal of Plant Pathology \& Microbiology, 2013. 04(06), 1-5.

55. CLSI. Performance standards for antimicrobial susceptibility testing; twenty-fourth international supplement. Wayne, PA: Clinical Laboratory and Standards Institute. 2014.

56. Nair DN, Padmavathy S. Impact of endophytic microorganisms on plants, enviornment and humans. The Scientific World Journal. 2014. 2014(250693):1-11.

57. Ismail, Hamayun M, Hussain A, Iqbal A, Khan SA, Lee IJ. Endophytic fungus Aspergillus japonicus mediates host plant growth under normal and heat stressed conditions. BioMed Research International. 2018. 2018(3):1-11.

58. Ghanta, R., Dutta, S. \& Mukhopadhyay, R. (2012). Occurrence of dark septate endophytes in the sporophytes of Christella dentata. American Fern Journal, 102(3), 216-223.

59. Tan RX, Zou WX. Endophytes: a rich source of functional metabolites. Natural Product Reports. 2001. 18(4):448-459.

60. Bacon CW, White JF. Microbial endophytes. New York, N.Y.: Marcel Dekker, Inc. 2000.

61. Strobel G, Daisy B. Bioprospecting for microbial endophytes and their natural products. Microbiology and Molecular Reviews. 2003. 67(4):491-502. 
62. Nisa H, Kamili AN, Nawchoo IA, Bhat MS, Nazir R. Isolation and identification of endophytic fungi from Artemisia scoparia (Asteraceae). International Journal of Theoretical and Applied Sciences. 2018. 10(1):83-88.

63. Zelicourt AD, Al-Yousif M, Hirt H. Rhizosphere microbes as essential partners for plant stress tolerance. Molecular Plant. 2013. 6(2): 242-245.

64. Salas-Marina MA, Silva-FLores MA, Cervantes-Badillo MG, Rosales-Saavedra MT, Islas-Osuna MA, Casa-Flores S. The plant growth-promoting fungus Aspergillus ustus promotes growth and induces resistance agaisnt lifestyle pathogens in Arabidopsis thaliana. Journal of Microbiology and Biotechnology. 2011. 21(7):686-96.

65. Kumari M, Taritla S, Sharma A, Jayabaskaran C. Antiproliferative and antioxidative bioactive compounds in extracts of marinederived endophytic fungus Talaromyces purpureoogenus. Frontiers in Microbiology. 2018. 9(177):1-12.

66. Ismail, Hamayun M, Hussain A, Khan SA, Iqbal A, Lee IJ. Aspergillus flavus promoted the growth of soybean and sunflower seedlings at elevated temperature. BioMed Research International. 2019. 2019(1295457):1-13.

67. McLellan CA, Turbyville TJ, Wijeratne EMK, Kerschen A, Vierling $\mathrm{E}$, Queitsch C, Whitesell L, Gunatilaka AAL. A rhizosphere fungus enhances Arabidopsis Thermotolerance through production of an HSP90 inhibitor. Plant Physiology. 2007. 145(1):174-82.

68. Suarez-Estrella F, Vargas-Garcia C, Lopez MJ, Capel C, Moreno J. Antagonistic activity of bacteria and fungi from horticultural compost against Fusarium oxysporum f.sp. melonis. Crop Protection. 2007. 26(1):46-53.

69. Kandhari J, Majumder S, Sen B. Impact of Aspergillus niger AN27 on growth promotion and sheath blight disease reduction in rice. 2000. 25(3):21-2.

70. Rai B, Upadhyay RS. Competitive saprophytic colonization of pigeonpea substrate by Fusarium udum in relation to environmental factors, chemical treatments and microbial antagonism. Soil Biology and Biochemistry. 1983. 15(2):187-191.

71. Hruska Z, Rajasekaran K, Yao H, Kincaid R, Darlington D, Brown RL, Bhatnagar D, Cleveland TE. Co-inoculation of aflatoxigenic and non-aflatoxigenic strains of Aspergillus flavus to study fungal invasion, colonization, and competition in maize kernels. Frontiers in Microbiology. 2014. 5(122):1-7.

72. Kagot V, Okoth S, de Boevre M, de Saeger S. Biocontrol of Aspergillus and Fusarium mycotoxins in Africa: Benefits and limitations. Toxins. 2019. 11(109):1-9.

73. Budge SP, Whipps JM. Potential for integrated control of Sclerotinia sclerotiorum in glasshouse lettuce using Coniothyrium minitans and reduced fungicide application. Biological Control. 2000. 91(2): 221-227.

74. de Vrije T, Antoine N, Buitelaar RM, Bruckner S, Dissevelt M, Durand A, Gerlagh M, Jones EE, Lüth P, Oostra J, Ravensberg WJ, Renaud R, Rinzema A, Weber FJ, Whipps JM. The fungal biocontrol agent Coniothyrium minitans: Production by solid-state fermentation, application and marketing. Applied Microbiology and Biotechnology. 2001. 56:58-68.

75. Gerlagh M, Goossen-van de Gejin HM, Fokkema NJ, Verreijken PFG. Long-term biosanitation of Coniothyrium minitans on Sclerotinia sclerotium-infected crops. Phytopathology. 1999. 89(2):141-147.

76. Huang HC. Control of sclerotinia wilt of sunflower by hyperparasites. Canadian Journal of Plant Pathology. 1980. 2(1):26-32.

77. Li GQ, Huang HC, Miao HJ, Erickson RS, Jiang DH, Xiao YN. Biological control of sclerotinia diseases of rapeseed by aerial applications of the mycoparasite Coniothyrium minitans. European Journal of Plant Pathology. 2006. 114:345-355.

78. Partridge DE, Sutton TB, Jordan DL, Curtis VL, Bailey JE. Management of sclerotinia blight of peanut with the biological control agent Coniothyrium minitans. Plant Disease. 2006. 90(7):957-63

79. Rabeendran N, Jones EE, Moot DJ, Stewart A. Biocontrol of Sclerotinia lettuce drop by Coniothyrium minitans and Trichoderma hamatum. Biological Control. 2006. 39(3):352-62.
80. Turner GJ, Tribe HT. Preliminary field plot trials on biological control of Sclerotinia trifoliorum by Coniothyrium minitans. Plant Pathology. 1975. 109-113.

81. Yang R, Han Y, Li G, Jiang D, Huang HC. Effects of ambient $\mathrm{pH}$ and nutritional factors on antifungal activity of the mycoparasite Coniothyrium minitans. Biological Control. 2008. 44(1):116-27.

82. McQuilken MP, Gemmell J, Hill RA, Whipps JM. Production of macrosphelide A by the mycoparasite Coniothyrium minitans. FEMS Microbiology Letters. 2003. 219(1):27-31.

83. McQuilken MP, Gemmell J, Whipps JM. Some nutritional factors affecting production of biomass and antifungal metabolites of Coniothyrium minitans. Biocontrol Science and Technology. 2002. 12(4):443-54.

84. Yang R, Han YC, Li GQ Jiang DH, Huang HC. Suppression of Sclerotinia sclerotiorum by antifungal substances produced by the mycoparasite Coniothyrium minitans. European Journal of Plant Pathology. 2007.119(4):411-20.

85. Fravel D, Olivain C, Alabouvette C. Fusarium oxysporum and its biocontrol. New Phytopathologist Trust. 2003. 157(3):493-502.

86. Kaur R, Kaur J, Singh RS. Nonpathogenic Fusarium as a biological control agent. Plant Pathology Journal. 2010. (9)3:79-91.

87. Gerlach KS, Bentley S, Moore NY, Aitken EAB, Pegg KG. Investigation of non-pathogenic strains of Fusarium oxysporum for suppression of Fusarium wilt of banana in Australia. Second International Fusarium Workshop, 1999. (p. 54). Dijon, France: INRA-CMSE.

88. Lemanceau P, Bakker PAHM, De Kogel WJ, Alabouvette C., Schippers B. Antagonistic effect on nonpathogenic Fusarium oxysporum strain Fo47 and pseudobactin 358 upon pathogenic Fusarium oxysporum f.sp. Dianthi. Applied and Environmental Microbiology. 1993. 59(1):74-82.

89. Tezuka N, Makino T. Biological control of Fusarium wilt of strawberry by nonpathogenic Fusarium oxysporum isolated from strawberry. Annals of Phytopathology Society of Japan. 1991. 506-11.

90. Larsen TO, Lange L, Schnorr K, Stender S, Frisvad JC. Solistatinol, a novel phenolic compactin analogue from Penicillium solitum. Tetrahedron Letters. 2007. 48(7):1261-4.

91. Frisvad JC, Smedsgaard J, Larsen TO, Samson RA. Mycotoxins, drugs and other extrolites produced by species in Penicillium subgenus Penicillium. Studies in Mycology. 2004. 49:201-41.

92. Khokhar I, Mukhtar I, Mushtaq S. Antifungal effect of Penicillium metabolites against some fungi. Archives of Phytopathology and Plant Protection. 2011. 44(14):1347-51.

93. Nicoletti R, Lopez-Gresa MP, Manzo E, Carella AA, Clavatta ML. Production and fungitoxic activity of Sch 642305, a secondary metabolite of Penicillium canescens. Mycopathologia. 2007. 163(5): 295-301.

94. Park MS, Fong JJ, Oh SY, Kwon KK, Sohn JH, Lim YW. Marinederived Penicillium in Korea: Diversity, enzyme activity, and antifungal properties. Antonie van Leeuwenhoek. 2014. 106:331-45.

95. De Stefano S, Nicoletti R, Milone A, Zambardino S. 3-O-Methylfunicone, a fungitoxic metabolite produced by the fungus Penicillium pinophilum. Phytochemistry. 1999. 14(2):1399-1401.

96. Nicoletti R, Trincone A. Bioactive compounds produced by strains of Penicillium and Talaromyces of marine origin. Marine Drugs. 2016. 14(2):1-35.

97. Nicoletti R, de Stefano M, de Stefano S, Trincone A, Marziano F. Antagonism against Rbizoctonia solani and fungitoxic metabolite production by some Penicillium isolates. Mycopathologia. 2004. 158(4):465-74.

98. Oxford AE, Raistrick H. Simonart, P. Studies in the biochemistry of micororganisms. LX. Griseofulvin, $\mathrm{C} 17 \mathrm{H} 17 \mathrm{O} 6 \mathrm{Cl}$, a metabolic product of Penicillium griseofulvum Dierckx. Biochemical Journal. 1939. 33(2):240-8.

99. Vinale F, Sivasithamparam K, Ghisalberti EL, Woo SL, Nigro M, Marra R, et al. Trichoderma secondary metabolites active on plants and fungal pathogens. The Open Mycology Journal. 2014. 8:127-39.

100. Santos SS, Augusto DG, Casaes Alves PA, Pereira JS, Duarte LMB, Melo PC, Gross E, Kaneto CM, Santos JL. Trichoderma asperelloides ethanolic extracts efficiently inhibit Staphylococcus growth and biofilm formation. PLOS One. 2018. 13(8):e0202828. 
101. Salas-Marina MA, Silva-FLores MA, Cervantes-Badillo MG, Rosales-Saavedra MT, Islas-Osuna MA, Casa-Flores S. The plant growth-promoting fungus Aspergillus ustus promotes growth and induces resistance against lifestyle pathogens in Arabidopsis thaliana. Journal of Microbiology and Biotechnology. 2011. 21(7):686-96.

102. Vizcaino JA, Sariz L, Basilio A, Vicente F, Gutierrez S, Hermosa MR, Monte E. Screening of antimicrobial activities in Trichoderma isolates representing three Trichoderma sections. Mycological Research. 2005. 109(12):397-1406.

103. Schnürer J, Olsson J, Borjesson T. Fungal volatiles as indicators of food and feeds spoilage. Fungal Genetics and Biology. 1999. 27(2-3): 209-17.

104. Nguyen TTT, Paul NC, Lee HB. Characterization of Paecilomyces variotii and Talaromyces amestolkiae in Korea based on the morphological characteristics and multigene phylogenetic analyses. Mycobiology. 2016. 44(4):248-59.

105. Nicoletti R, Salvatore MM, Andolfi A. Secondary metabolites of mangrove-associated strains of Talaromyces. Marine Drugs. 2018. 16(1):1-15.

106. Liu F, Cai XL, Yang H, Xia XK, Guo ZY, Yuan J, Li MF, She ZG, Lin YC. The bioactive metabolites of the mangrove endophytic fungus Talaromyces sp. ZH-154 isolated from Kandelia candel (L.) Druce. Natural Product Chemistry. 2010. 76(2):185-9.

107. Kim KK, Fravel DR, Papavizas GC. Glucose oxidase as the antifungal principle of talaron from Talaromyces flavus. Canadian Journal of Microbiology. 1990. 36(11):760-4.

108. Kim MJ, Shim CK, Kim YK, Hong SJ, Park JH, Han EJ, Kim SC. Enhancement of seed dehiscence by seed treatment with Talaromyces favus GG01 and GG04 in ginseng (Panax ginseng). Plant Pathology Journal. 2017. 33(1):1-8.

109. Leylaie S, Zafari D. Antiproliferative and antimicrobial activities of secondary metabolites and phylogenetic study of endophytic Trichoderma species from Vinca plants. Frontiers in Microbiology. 2018. 9(1484):1-16

110. Salas-Marina MA, Silva-FLores MA, Cervantes-Badillo MG, Rosales-Saavedra MT, Islas-Osuna MA, Casa-Flores S. The plant growth-promoting fungus Aspergillus ustus promotes growth and induces resistance against lifestyle pathogens in Arabidopsis thaliana. Journal of Microbiology and Biotechnology. 2011. 21(7):686-96.

111. Vizcaino JA, Sariz L, Basilio A, Vicente F, Gutierrez S, Hermosa MR, Monte E. Screening of antimicrobial activities in Trichoderma isolates representing three Trichoderma sections. Mycological Research. 2005. 109(12):397-1406.

112. Schnürer J, Olsson J, Borjesson T. Fungal volatiles as indicators of food and feeds spoilage. Fungal Genetics and Biology. 1999. 27(2-3): 209-17.

113. Turnidge J, Gottlieb T, Mitchell D, Daley D, Bell J. Susceptibility testing results. In: Gram Negative Survey 2012 Antimicrobial Susceptibility Report. Australia: Australian Group on Antimicrobial Resistance (AGAR). 2013.15.
114. Gangcuangco LM, Alejandria M, Henson KE, Alfaraz L, Ata RM, Lopez M, Saniel M. Prevalence and risk factors for trimethoprimsulfamethoxazole resistant Escherichia coli among women with acute uncomplicated urinary tract infection in a developing country. Int J Infect Dis, 2015. 34:55-60.

115. Serrano GL, Penuliar GM. Prevalence, antibiogram and virulence gene profiles of uropatogenic Escherichia coli from pregnant women with urinary tract infection. Philippine Science Letters. 2018. 11:59-68.

116. Chambers HF, DeLeo FR. Waves of resistance: Staphylococcus aureus in the antibiotic era. Nature Reviews in Microbiology, 2009. 7(9), 629-41.

117. Deyno S, Fekadu S, Astatkie A. Resistance of Staphylococcus aureus to antimicrobial agents in Ethiopia: a meta-analysis. Antimicrobial Resistance \& Infection Control, 2017. 6(85).

118. Ciffo F. Determination of the spectrum of antibiotic resistance of the "Bacillus subtilis" strains from Enterogermina. Chemioterapia, 1984. 3, 45-52.

119. Green DH, Wakeley PR, Page A Barnes A, Baccigalupi L, Ricca E, Cutting SM. Characterization of two Bacillus probiotics. Applied and Environmental Microbiology, 1999. 65(9), 4288-91.

120. Hoa NT, Baccigalupi L, Huxham A, Smertenko A, Van PH, Ammendola S, Ricca E, Cutting AS. Characterization of Bacillus species used for oral bacteriotherapy and bacterioprophylaxis of gastrointestinal disorders. Applied and Environmental Microbiology, 2000. 66(12), 5241-7.

121. Mazza P, Zani F, Martelli P. Studies on the antibiotic resistance of Bacillus subtilis strains used in oral bacteriotherapy. Bolletino Chimico Farmaceutico, 1992.131, 401-8.

122. Adimpong DB, Serensen KI, Thorsen L, Stuer-Lauridsen B, Abdelgadir WS, Nielsen DS, Derkx PMF, Jerpersen L. Antimicrobial Susceptibility of Bacillus strains isolated from primary starters for African traditional bread production and characterization of the bacitracin operon and bacitracin biosynthesis. Applied and Environmental Microbiology, 2012. 78(22), 7903-14.

123. Gevers D, Masco L, Baert L, Huys G, Debevere J, Swings J. Prevalence and diversity of tetracycline resistant lactic acid bacteria and their tet genes along the process line of fermented dry sausages. Systematic and Applied Microbiology, 2003. 26(2), 277-83.

124. Nam MH, Park MS, Kim HS, Kim TI, Kim HG. Cladosporium cladosporioides and C. tenuiissimum cause Blossom blight in strawberry in Korea. Mycobiology, 2015. 43(3):354-9.

125. Tashiro N, Noguchi M, Ide Y, Kuchiki F. Sooty spot caused by Cladosporium cladosporioides in postharvest Satsuma mandarin in heated greenhouses. Journal of General Plant Pathology, 2013. 79(2):158-61. 